\title{
Comparison of methods for the determination of the pore system of a potential German gas shale
}

\section{Book Chapter}

\section{Author(s):}

Kaufhold, Stephan; Grathoff, Georg; Halisch, Matthias; Plötze, Michael; Kus, Jolanta; Ufer, Kristian; Dohrmann, Reiner; Ladage, S.; Ostertag-Henning, Christian

\section{Publication date:}

2016

\section{Permanent link:}

https://doi.org/10.3929/ethz-a-010668928

Rights / license:

In Copyright - Non-Commercial Use Permitted

Originally published in:

The Clay Minerals Society Workshop Lectures Series 21 


\title{
COMPARISON OF METHODS FOR THE DETERMINATION OF THE PORE SYSTEM OF A POTENTIAL GERMAN GAS SHALE
}

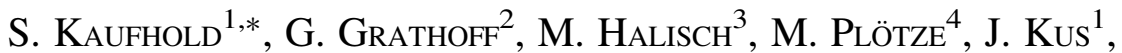 \\ K. Ufer ${ }^{1}$, R. Dohrmann ${ }^{1,5}$, S. Ladage ${ }^{1}$, and Ch. Ostertag-Henning ${ }^{1}$ \\ ${ }^{1}$ BGR, Bundesanstalt für Geowissenschaften und Rohstoffe, Stilleweg 2, \\ D-30655 Hannover, Germany \\ ${ }^{2}$ Ernst-Moritz-Arndt Universität Greifswald, Institute for Geography and Geology, \\ Friedrich-Ludwig-Jahn-Str. 17a, D-17487 Greifswald, Germany \\ ${ }^{3}$ Leibniz Institute for Applied Geophysics (LIAG), Stilleweg 2, \\ 30655 Hannover, Germany \\ ${ }^{4}$ ETH Zurich, Institute for Geotechnical Engineering, \\ 8093 Zurich, Switzerland \\ ${ }^{5}$ LBEG, Landesamt für Bergbau, Energie und Geologie, Stilleweg 2, \\ D-30655 Hannover, Germany \\ *e-mail: s.kaufhold@bgr.de
}

\begin{abstract}
The aim of the present study was to investigate the porosity of the Posidonia shale as a potential gas shale and to compare the results with data published on gas shales known to be productive. The characterization of the porosity of clays and shales still poses an analytical challenge, however. Different methods were investigated based on a comparison of four different Posidonia shales, with different degrees of maturity. Both direct microscopical methods as well as indirect methods based on gas adsorption or $\mathrm{Hg}$ intrusion were applied. Most of the pores in clays and shales were too small to be detected by any of the existing direct methods. About $80 \%$ of the pores were $<30 \mathrm{~nm}$ wide. The Posidonia shales, as is the case with most shales, are dominated by mesoporosity (ranging from 20 to $50 \mathrm{~mm}^{3} / \mathrm{g}$ ). The mesopore peak representing the average pore diameters could be resolved by $\mathrm{Hg}$ intrusion and was found to decrease with increasing maturity which may be explained by increased compaction and/or temperature. This relation, if not applicable to the entire Posidonia shale, may be restricted to a single sedimentary system (e.g. a basin or a sequence). The results of the indirect methods (except for $\mathrm{CO}_{2}$ microprosity) were comparable and this might be explained by the low macroporosity. The most important question concerning shale-gas production and porosity relates to the pore diameter needed to allow gas migration. Natural gas in micropores may be bound too strongly to liberate it without low pressure/vacuum. For gas production either meso- or macropores may be important. Notably, all methods used for characterization of porosity were performed on dry samples. A nm-scale connectivity determined at an illite-smectite interface pore is not supposed to provide a gas pathway in the water-saturated state. Prediction of the gas-production potential from porosity measurements has not been possible to date, therefore. Taking the organic carbon content, vitrinite reflectance, and comparison of the porosity with that of North American gas shales into account, however, indicates potential for the Posidonia shale which still has to be proven by shale-gas production tests.
\end{abstract}




\section{Introduction}

Oil and gas are usually pumped out of porous rocks in which they were entrapped. The resources formed in the so-called 'source rocks' and migrated into the so-called 'reservoir rocks.' Such deposits are referred to as 'conventional deposits.' Appreciable hydrocarbons exist in less porous rocks, however, and that has been the location for most of them since the time of formation ('unconventional deposits') because these rocks are 'tight.' Commonly, gas shales are distinguished from other tight gas deposits. The hydrocarbons of the tight rocks cannot be produced using conventional techniques the tight rocks have to be fractured hydraulically before the hydrocarbons can be extracted. Production is achieved by a technique called hydraulic fracturing (otherwise known as 'fracking'). The tight rocks are fractured using high-pressure water pulses. This technique is sometimes even used for conventional deposits to maximize the output. For some kinds of rocks the cracks or fracks have to be kept open which is achieved by small glass or sand particles inserted along with chemicals preventing microbial growth which also could reduce permeability. For exploitation of unconventional deposits, directed and/or horizontal drilling is the state of the art. Due to the growing economic importance of both unconventional oil and gas deposits many countries have begun to investigate their tight gas/oil potential. In the USA, unconventional deposits already provide a significant proportion of national energy resources (about 30\% in 2011, Blumsack, 2014). Tight-gas production in the USA doubled between 1990 and 2010. The amount of shale-gas production was insignificant in 2000 but started to increase significantly after 2005, as it is the most important tightgas deposit type (Blumsack, 2014). In Europe, unconventional deposits are much less prominent although several interesting formations exist. A description of American gas shales was given by Curtis (2002).

From a scientific point of view, however, these new deposits and the technology used raise several unanswered questions. The most important ones probably concern mechanisms of hydrocarbon migration through the more or less tight and/or fractured rocks. Characterization of the porosity of tight rocks, e.g. of the so-called gas shale, is particularly relevant. Of the different types of tight rocks, gas shales are interesting from a scientific point of view mainly because of the analytical challenges. A potential gas shale should contain clay minerals or at least clay-sized particles $(<2 \mu \mathrm{m})$ and a significant proportion of organic matter. The porosity of gas shales is also known to be important (Chalmers et al., 2012a). The characterization of the porosity of gas shales or clays in general, however, is still an analytical challenge. Correlation of the pore-size distribution with gas diffusivity or migration is difficult in general because of the fact that important small pores appear to be beyond the detection limit of analytical methods.

Two different types of methods to determine the porosity of rocks can be distinguished - direct and indirect. Direct methods are based on microscopic investigations. Because of the small size of the shale pores, electron microscopy is used for any clayrelated material. Recently, scanning electron microscopy (SEM) has been combined successfully with ion milling (either with a focused or a slightly broader ion beam). 
With this technique a set of the common 2D SEM images is recorded, each after removing the next few $\mathrm{nm}$. After reasonable and non-trivial image processing, a 3D image is obtained (e.g. Warr and Grathoff, 2011). Using the focused ion beam (FIB) a resolution of $10 \mathrm{~nm}$ is often reported (Curtis et al., 2010; Keller et al., 2011; Chalmers et al., 2012b). Using Ar ion milling, Loucks et al. (2009) reported a resolution of $\sim 5 \mathrm{~nm}$. The disadvantage of FIB/BIB (BIB = broad ion beam) systems is the small volume of the sample examined; this may not be representative of the sample as a whole. Using $\mu$-CT, a much larger volume (typically $\sim 1 \mathrm{~mm}^{3}$ ) can be investigated. The spatial (= voxel) resolution, however, is commonly no better than 2-3 $\mu \mathrm{m}$. State-of-the-art $\mu$-CT scanners can achieve 3D resolutions in the submicron range $(\sim 700 \mathrm{~nm})$ for very small samples and regions of interest, as shown by Dultz et al. (2014) for the investigation of bio-alteration effects in basalt. A much better resolution $(\sim 30-50 \mathrm{~nm})$ can be attained using synchrotron-CT $(\mathrm{S}-\mathrm{CT})$ which is rarely applied in clay science, however (e.g. Viggiani et al., 2013). High-resolution transmission electron microscopy (HRTEM) is rarely used to characterize pores of gas shales (e.g. Kennedy et al., 2014), which may be the result of difficult sample preparation because the preparation of ultra-thin sections may produce microstructural artefacts. The most common indirect methods to characterize the porosity of clayrelated materials are $\mathrm{Hg}$ intrusion and gas adsorption (commonly using $\mathrm{N}_{2}$ but $\mathrm{CO}_{2}$, $\mathrm{He}$, and Ar are also used).

For clay-pore classification, IUPAC-based terminology is used mostly (IUPAC, 1994). This classification is based largely on gas-adsorption processes. In micropores (up to $2 \mathrm{~nm}$ ), gas molecules are much more strongly adsorbed than in mesopores $(2-50 \mathrm{~nm})$. Mesopores are large enough for a fluid to form which in turn results in a meniscus at the pore mouth. Adsorption in larger pores (macropores: $>50 \mathrm{~nm}$ ) is less specific. Pores of sediments are classified according to their shape and associated particles and these are analyzed by microscopical methods. A classification of gas-shale pores would, however, be restricted to the macropores because of the resolution of most SEM instruments. Different types of pores were distinguished. In the Barnett shale, (USA) the most abundant elliptical intraorganic pores $(5-750 \mathrm{~nm})$ were distinguished by Loucks et al. (2009) from the less abundant interparticle pores and pores occurring in pyrite framboids. Five different types of pores were established by Schieber (2011): (1) framework pores determined by open spaces of the fabric; (2) intrapores are integral to certain grain types; (3) solvopores result from dissolution; (4) macerapores occur in organic matter; and (5) desipores form by shrinkage caused by storage of the cores. The pore classification of Curtis et al. (2010) who investigated a set of the most important American gas shales is closer to that of Loucks et al. (2009). In the first instance, intraorganic pores were distinguished from inorganic matrix pores. The latter may be crack-like or related to phyllosilicates. With respect to gas shales, distinguishing intraorganic from inorganic pores appears to be possible because intraorganic pores result from the formation of gas and oil from the organic matter and the affinity of pores within organic particles toward gas is greater than that for the inorganic pores. Interparticle pores of the dominant inorganic matrix, however, may be more important with respect to possible gas production. 
The determination of the pore-size distribution of gas shales is still an analytical challenge, mostly because the bulk porosity is beyond the detection limit of direct methods. As a result, two kinds of methods, direct and indirect, are used. The results of all methods have artefacts associated with them, however. All results have to be considered critically, therefore. Most often, an ion-milling technique (FIB or BIB) is compared with either Hg intrusion (Klaver et al., 2012) or gas adsorption (Keller et al., 2011). Most of the studies agree that shale-gas pores are predominantly in the nm range (Loucks et al., 2009). The Opalinus clay, which is a potential host rock for highly radioactive waste rather than a gas shale, was examined by Keller et al. (2011, 2013). Comparing $\mathrm{N}_{2}$ adsorption and FIB, those authors concluded that only $20 \%$ of the total porosity could be visualized. About $80 \%$ of the porosity may be below the FIB resolution of $10 \mathrm{~nm}$, therefore. An additional TEM study revealed the smaller pores. The Marcellus formation (USA) was investigated by Milliken et al. (2013) who could also visualize only $2-30 \%$ of the total porosity. The "transition from an unconnected to a connected pore space in the shale sample occurs on the few nanometers scale" was the conclusion arrived at by Keller et al. (2013) and this is in agreement with Klaver et al. (2012) who investigated the potential German Posidonia gas shale and stated the existence of pore throats at $<10 \mathrm{~nm}$. The total porosity of some North American gas shales ranges from 2 to $7 \%$ (Chalmers et al., 2012a, 2012b; Klaver et al., 2012). The microporosity is $\sim 0.1-1 \mathrm{~mL} / 100 \mathrm{~g}$ (Ross and Bustin, 2009; Chalmers et al., 2012a) and the mesoporosity somewhat larger ((meso + macroporosity $1-3 \mathrm{~mL} / 100 \mathrm{~g}))($ Chalmers et al., 2012a).

Note that the pore volumes determined by any adsorbate other than methane cannot be transferred directly to a methane-accessible volume. Note that not all of the micropore volume determined with $\mathrm{He}$ is accessible to methane (Ross and Bustin, 2007). The migration of different gas molecules is different because of the small scale of the pores. The importance of considering the kinetic diameter which is larger for $\mathrm{CO}_{2}$ than for methane or $\mathrm{N}_{2}$, for example, was stressed by Cui et al. (2004). For production of shale gas, however, macroporosity is essential (Ropertz, 1994). In micropores, on the other hand, gas molecules are believed to be adsorbed strongly. Methane bound to micropores has to be forced to leave the pore, by temperature and/or low pressure/vacuum. Methane adsorbed in micropores, therefore, may not be producible from gas shale.

The Posidonia shale is one of the potential German gas shales. The Hilsmulde, in particular, was investigated with respect to evolution of hydrocarbons and porosity within the shale (Littke et al., 1987; Rullkötter et al., 1988; Ropertz, 1994; Bernard et al., 2012; Kanitpanyacharoen et al., 2012; Klaver et al., 2012) because of the opportunity to study samples with different degrees of maturity. The geography and geology have been explained in detail, e.g. by Littke et al. (1987), and are not repeated here. The porosity was determined by Ropertz (1994) who found higher values in calcareous material. The values determined by $\mathrm{N}_{2}$ adsorption and $\mathrm{Hg}$ intrusion, however, were somewhat lower than those reported for the American gas shales (Chalmers et al., 2012a). Porosity was characterized recently by high-pressure methane adsorption (Rexer et al., 2014). 
The key problem in understanding the hydrocarbon potential of gas shales probably results from the fact that all shales are different. They differ with respect to their mineralogical composition and microfabric (relative arrangement of all particles to each other and particle-size distribution), organic-carbon content, and maturity. The burial history may also affect the properties of the shales. The economic values of the different gas shales cannot be predicted based on the results published to date. Some systematic relations were found, however. A positive correlation between gasadsorption capacity, microporosity, and organic matter content was established by Ross and Bustin (2009). More microporosity was found (Chalmers et al., 2012a) in samples with low porosity. Samples with larger total porosity values showed more mesoporosity. A positive correlation between the quartz content, organic material, and porosity was established by Chalmers et al. (2012b). The porosity generally increases with increasing clay and/or detrital quartz content but decreases with increasing carbonate and/or biogenic quartz content (Ross and Bustin, 2008).

In the present study the potential German Posidonia gas shale was investigated. The aim was to compare direct and indirect methods for the characterization of the pore system and to compare the pore system of the Posidonia shale with that of well known gas shales.

\section{Materials and methods}

Samples from four drill sites in or near the Hils syncline in the Lower Saxony Basin (Germany) were selected for the present study. The cores with a diameter of $10 \mathrm{~cm}$ at each site have recovered a complete sequence of the Posidonia shale unaffected by weathering or by groundwater alteration. The locations (Wickensen, Dohnsen, Dielmissen, Haddessen) were targeted because of a very similar facies of the Posidonia shale but with different levels of thermal maturity. Detailed descriptions of the cores, and of their sedimentological and geochemical features, have been published (e.g. Mann, 1987; Littke et al., 1988; Rullkötter et al., 1988). In the following text the samples are designated by abbreviations related to their drill locations, i.e. WIC for Wickensen, DIE for Dielmissen, DOH for Dohnsen, and HAD for Haddessen.

The chemical compositions of powdered samples were determined using a PANalytical Axios spectrometer (Almelo, Netherlands). Samples were prepared by mixing with a flux material (Lithium metaborate Spectroflux, Flux No. 100A, Alfa Aesar) and melting into glass beads. The beads were analyzed by wavelength dispersive X-ray fluorescence spectrometry (WD-XRF). To determine loss on ignition (LOI), $1000 \mathrm{mg}$ of sample material was heated to $1030^{\circ} \mathrm{C}$ for $10 \mathrm{~min}$.

The quantitative mineralogical composition was calculated based on X-ray diffraction patterns recorded using a PANalytical X'Pert PRO MPD $\theta-\theta$ diffractometer (Almelo, Netherlands) (CoK $\alpha$ radiation generated at $40 \mathrm{kV}$ and $40 \mathrm{~mA}$ ), equipped with a variable divergence slit (20 mm irradiated length), primary and secondary soller slits, diffractedbeam monochromator, and a point detector. After back loading, the samples were investigated from 1 to $65^{\circ} 2 \theta$ with a step size of $0.03^{\circ} 2 \theta$ and a measuring time of $5 \mathrm{~s}$ 
per step in air-dried conditions. The patterns were refined using the Rietveld code, BGMN. The resulting quantitative compositions were then optimized by taking the chemical composition into consideration (X-ray fluorescence, elemental analysis).

Bulk samples of $170-180 \mathrm{mg}$ of the dried material were used to measure the total carbon (TC) content with a LECO CS-444-Analyzer. The total organic carbon $\left(\mathrm{C}_{\text {org }}\right)$ content (TOC) was measured after dissolution of the carbonates. Carbonates had been removed by treating the samples several times with $\mathrm{HCl}$ at $80^{\circ} \mathrm{C}$ until no further gas evolution could be observed. Total inorganic carbon (TIC, $\mathrm{C}_{\text {anorg }}$ ) was calculated as the difference between TC and TOC. The samples were heated to $1800-2000^{\circ} \mathrm{C}$ in an oxygen atmosphere in the device and the $\mathrm{CO}_{2}$ was detected using an infrared detector (St. Joseph, Michigan, USA).

From the rock samples dried at $30^{\circ} \mathrm{C}$, crushed and sieved to $1 \mathrm{~mm}$ grain-size aliquots, and embedded and impregnated in an epoxy resin mixture, ground and polished pellets in wet and dry states were prepared. The petrographic analyses of dispersed organic matter were conducted following the German Standard Methods DIN 22020-5: 2005-02, DIN 22020-5:1986-09, and DIN 22020-5-1981-04, and the guidelines of Taylor et al. (1998). Random vitrinite reflectance measurements were carried out in non-polarized light, at a magnification of $500 \times$ and room temperature of $23 \pm 1{ }^{\circ} \mathrm{C}$ using a Leica DMRX incident light microscope equipped with an MPV Compact 2 microphotometer photomultiplier tube (PMT), halogen lamp $(12 \mathrm{~V}, 100 \mathrm{~W}), \mathrm{HBO}^{\circledR}$ Lamp $(103 \mathrm{~W} / 2,12 \mathrm{~V})$, and Leica Oil P $50 \times / 0.85$ oil immersion objective. Leica Type $\mathrm{F}$ immersion oil $\mathrm{n}_{\mathrm{e}}=1.518\left(23^{\circ} \mathrm{C}\right)$ as well as following synthetic glass and mineral standards $0.423,0.590,0.683$, and 1.005 for the purpose of calibration. Up to 30 reflectance measurements were performed on each sample using Leica MPV.Meas software. Each mean random vitrinite reflectance value was also subjected to an in-house qualifier system taking into account the evaluation of the surface structure of the vitrinite particles, the number of measurements, and the coefficient of variation. The filters used for analysis in blue fluorescent light were Leica excitation filter BP 355-425, dichroic mirror RKP 455, and barrier filter LP 460. Photomicrographs taken in incident bright and blue light excitation using a Leica digital fluorescence camera DFC300 FX at $1300 \times 1030$ pixels were stored using imaging software Image Access Premium 09 (www.imageaccess.de).

The total porosity (porosity $<50 \mu \mathrm{m}$ ) was determined according Webb and Orr (1997) using a Micromeritics AccuPyc 1330 He-pycnometer and a Micromeritics GeoPyc 1360 (Norcross, Georgia, USA) which utilizes free-flowing, finely divided, dry powder as the fluid medium instead of a liquid. The smallest diameter of these spheres is $\sim 50 \mu \mathrm{m}$. The porosity is, therefore, $<50 \mu \mathrm{m}$.

The $\mu$-CT scans were performed at the department of Petrophysics and Borehole Geophysics of the LIAG (Hannover, Germany) with a high-resolution X-ray CT system (nanotom S, GE Sensing and Inspection Technologies, product line of phoenix|x-ray, Wunstorf, Germany). The nanotom 180 was designed specifically for the investigation of small (rock) samples, to achieve 3D image data sets of high quality and with very high resolution (Brunke et al., 2008). This device is equipped with a special water-cooled nanofocus X-ray tube $(180 \mathrm{kV}, 15 \mathrm{~W})$, which allows 
several modes of operation depending on sample size and habit for best possible results. The minimum focal spot size is $\sim 0.6 \mu \mathrm{m}$ which increases significantly the image sharpness. The detector used a Hamamatsu CMOS flat-panel detector with a pixel pitch of $50 \mu \mathrm{m}$ and a maximum field of view (FOV) of $2300 \times 2300$ pixel (5 megapixel). The FOV can be (virtually) extended laterally by a factor of three so that even larger samples can be investigated with very high resolution. The acquisition and reconstruction software included allows parallelized, GPU-based image processing, resulting in reconstruction times for a $2000^{3}$ voxel volume of $<5 \mathrm{~min}$. More information about computed tomography and image reconstruction can be found in studies by Buzug (2005) and Grangeat (1990), among others. The general scanning workflow and sample preparation were described by Halisch (2013). For the present study, samples in the range of $3-4 \mathrm{~mm}$ in size were cut from larger rock samples so that voxel resolutions of $\sim 1.6 \mu \mathrm{m}$ were achieved. The $\mu$-CT parameters used and 3D volume information are summarized in Table 1.

The FIB-SEM analyses were performed at the University of Greifswald (Germany). A Zeiss Auriga instrument with EDX and FE-Cathode facilities was used. Back-scattered electron (BSE) and scanning electron (SE) images were collected at a current of $1.5 \mathrm{kV}$. A current of $500 \mathrm{pA}$ was used during the FIB slicing process, resulting in slices which were $25 \mathrm{~nm}$ thick. Voxel size is dependent on the slice thicknesses as well as on the magnification. The resulting voxel size was $40 \mathrm{~nm} \times 40 \mathrm{~nm} \times 25 \mathrm{~nm}$. Before slicing and viewing, the sample was sputtered with Pd to minimize charging. The Avizo ${ }^{\mathbb{C}}$-Fire software (http://www.fei.com/software/ avizo3d/) was used for qualitative and quantitative image analysis. Firstly, the original 400 BSE image $25 \mathrm{~nm}$-thick slices, were imported into Avizo ${ }^{\complement}$, aligned and cropped to $20 \mu \mathrm{m} \times 10 \mu \mathrm{m}$, making a $20 \mu \mathrm{m} \times 10 \mu \mathrm{m} \times 10 \mu \mathrm{m}$ volume, followed by: (1) correction of artefacts using non-local means within the Filter Sandbox tool; (2) binarizing the pore space, performed by using the interactive threshold tool; and (3) separating and labeling the individual pores. The pores separated were tested for axis connectivity and separated (sieved) into different size ranges. The diameters of individual pores were determined using the Feret diameter ( $3 d$ width) and for the connectivity, the Euler $3 \mathrm{~d}$ module was used.

The specific surface area was determined by $\mathrm{N}_{2}$ adsorption using a 5 point BET method (Brunauer et al., 1938). Samples were dried at $105^{\circ} \mathrm{C}$ and crushed to $<250 \mu \mathrm{m}$ prior to analysis. Measurements were performed using a Micromeritics

Table 1. Relevant $\mu$-CT scan and reconstructed volume parameter of the investigated shales.

\begin{tabular}{|c|c|c|c|c|c|c|c|c|}
\hline \multirow[t]{2}{*}{ Sample } & \multicolumn{2}{|c|}{ Tube } & \multicolumn{2}{|c|}{ Detector } & \multirow[t]{2}{*}{ Filter } & \multirow{2}{*}{$\begin{array}{l}\text { Resolution } \\
\quad(\mu \mathrm{m})\end{array}$} & \multirow{2}{*}{$\begin{array}{c}\text { ROI } \\
\text { size } \\
\text { (voxels) }\end{array}$} & \multirow{2}{*}{$\begin{array}{c}\text { Volume } \\
\left(\mathrm{mm}^{3}\right)\end{array}$} \\
\hline & $\begin{array}{c}\text { Voltage } \\
(\mathbf{k V})\end{array}$ & $\begin{array}{c}\text { Current } \\
(\mu \mathbf{A})\end{array}$ & Stacking & $\begin{array}{l}\text { Acquisition } \\
\text { time (ms) }\end{array}$ & & & & \\
\hline WIC 9 & 63 & 100 & 8 & 750 & $\mathrm{Cu}, 0.1 \mathrm{~mm}$ & 1.6 & $725^{3}$ & 1.561 \\
\hline DOH 10 & 60 & 105 & 5 & 750 & $\mathrm{Cu}, 0.1 \mathrm{~mm}$ & 1.2 & $725^{3}$ & 0.659 \\
\hline DIE 13 & 64 & 98 & 6 & 750 & $\mathrm{Cu}, 0.1 \mathrm{~mm}$ & 1.6 & $725^{3}$ & 1.561 \\
\hline HAD 10 & 64 & 98 & 8 & 750 & $\mathrm{Cu}, 0.1 \mathrm{~mm}$ & 1.6 & $475^{3}$ & 0.439 \\
\hline
\end{tabular}


Gemini III 2375 surface area analyzer with $\sim 300 \mathrm{mg}$ sample mass at $77 \mathrm{~K}$. The same device was used to record adsorption-desorption isotherms from which the poresize distribution was calculated (based on the Barret-Joyner-Haleda (BJH) model). Because of its greater diffusion rate at $77 \mathrm{~K}, \mathrm{CO}_{2}$ can enter smaller pores than $\mathrm{N}_{2}$. The microporosity, therefore, was determined with $\mathrm{CO}_{2}$ in addition to the $\mathrm{N}_{2}$ measurements. The $\mathrm{CO}_{2}$-adsorption and desorption isotherms were measured using an Autosorb-1MP instrument (Quantachrome, Germany) at $273 \mathrm{~K}$; this device allows measurements of absolute gas pressures up to $\sim 100 \mathrm{kPa}$, which corresponds to a relative pressure $p / p_{0}$ of $0.03(100 / 3500 \mathrm{kPa})$ giving an upper limit of measurable pore diameters of $1.5 \mathrm{~nm}$. Samples of $\sim 600 \mathrm{mg}$ were used and degassed for $15 \mathrm{~h}$ at $150^{\circ} \mathrm{C}$ before the measurement. For the calculation of the pore-size distribution from $\mathrm{CO}_{2}$ adsorption isotherms, mathematical procedures based on non-local density functional theory (NLDFT) and Monte Carlo (MC) simulations were used.

The mercury-intrusion measurements were carried out using Pascal model 140 and Pascal model 440 instruments (Porotec, Germany). The combination of these devices allowed the determination of pores of between $1.8 \mathrm{~nm}$ and $58 \mathrm{~nm}$ in size. First, the air-dry specimens were evacuated $(0.03 \mathrm{kPa})$ at room temperature for $2 \mathrm{~h}$. The measurements were then conducted by incrementing the pressure up to $400 \mathrm{MPa}$ on the sample immersed in the mercury. The rate of pressure increase was adjusted automatically in an advanced procedure with lower rates at lower pressure levels and during measured intrusion processes. The calculation of the pore-size distribution was based on the Washburn equation (Washburn, 1921).

\section{Results}

\subsection{Characterization of the samples}

The mineralogical compositions of the four different Posidonia shale samples is given in Table 2. Samples are dominated by carbonates (36-64 mass \%). The amount of clay minerals ranges from 20 to 40 mass $\%$ and much less quartz and feldspar were found. The carbonates consist predominantly of calcite. Only sample DOH contains appreciable amounts of ankerite and dolomite. Compared with the composition of samples from the North American gas shales (Barnett, Haynesville, Woodford, Marcellus, and Doig: Chalmers et al., 2012a; figure inserted in table 3) the Posidonia shale samples contain more carbonates and less quartz/feldspar. The chemical composition along with other basic parameters such as vitrinite reflectance, specific surface area, and total porosity are given in Tables 2 and 3.

The vitrinite reflectance ranges from $\sim 0.5$ to $1.5 \%$, which is representative of the range before, in, and above the oil and gas window. As expected, a correlation of the vitrinite reflectance with the organic matter content was found which can be explained by maturation of the organic matter.

The specific surface area (SSA) of clays is known to be determined by microporosity (e.g. Kaufhold et al., 2010). No correlation was, therefore, observed with the total 
Table 2. Mineralogical composition of the inorganic fraction of the four Posidonia shale samples.

$\begin{aligned} & \text { Mineralogical } \\ & \text { composition } \\ & \text { (XRD Rietveld) }\end{aligned}$
$\begin{array}{lllllllllll}\text { WIC 9 } \\ \text { DOH 10 }\end{array}$
HIE 13 10

Table 3. Chemical composition, vitrinite reflectance, specific surface area (SSA), and total porosity of the four Posidonia shale samples

\begin{tabular}{|c|c|c|c|c|c|c|c|c|c|c|c|c|c|c|c|c|c|}
\hline & \multirow{2}{*}{$\begin{array}{l}\text { Vitrinite } \\
\text { reflection } \\
(\%)\end{array}$} & \multirow{2}{*}{$\begin{array}{c}\text { SSA } \\
\mathbf{N}_{2} \\
\left(\mathbf{m}^{2} / \mathbf{g}\right)\end{array}$} & \multirow{2}{*}{$\begin{array}{c}<\mathbf{5 0} \boldsymbol{\mu m} \\
\text { porosity } \\
(\%)\end{array}$} & \multicolumn{12}{|c|}{ Chemical composition (XRF) } & \multicolumn{2}{|c|}{ C-Analysis } \\
\hline & & & & $\mathrm{SiO}_{2}$ & $\mathrm{TiO}_{2}$ & $\begin{array}{r}\mathrm{Al}_{2} \mathbf{O}_{3} \\
\text { (mas }\end{array}$ & $\begin{array}{l}\mathrm{Fe}_{2} \mathrm{O}_{3} \\
\mathrm{ss} \%)\end{array}$ & MgO & $\mathrm{CaO}$ & $\begin{array}{c}\mathrm{Na}_{2} \mathrm{O} \\
(\operatorname{mass} \%)\end{array}$ & $\begin{array}{c}\mathbf{K}_{2} \mathbf{O} \\
(\mathbf{m a s s} \%)\end{array}$ & $\mathbf{P}_{2} \mathbf{O}_{5}$ & $\left(\mathrm{SO}_{3}\right)$ & LOI & Sum & $\underset{(\text { mass\% } \%)}{\mathbf{C}_{\text {anorg }}}$ & $\underset{(\mathrm{mass} \%)}{\mathbf{C}_{\text {org }}}$ \\
\hline WIC 9 & 0.49 & 9.8 & 15 & 18 & 0 & 6 & 4 & 1 & 29 & 0 & 1 & 0 & 6 & 33 & $\begin{array}{l}99 \\
\end{array}$ & 6.2 & 8.5 \\
\hline DOH 10 & 0.7 & 4.7 & 7 & 19 & 0 & 6 & 4 & 4 & 28 & 0 & 1 & 0 & 6 & 30 & 100 & 6.9 & 6.4 \\
\hline DIE 13 & 0.65 & 9 & 12 & 33 & 1 & 12 & 5 & 1 & 18 & 0 & 2 & 0 & 7 & 21 & 100 & 3.7 & 7.2 \\
\hline HAD 10 & 1.42 & 15.5 & 10 & 32 & 0 & 11 & 3 & 1 & 21 & 1 & 2 & 0 & 4 & 23 & 100 & 4.5 & 5.2 \\
\hline
\end{tabular}


porosity. The largest SSA was found for the sample with the largest vitrinite reflectance. In the case of clays with small organic matter contents a correlation of the SSA with the clay content or even with the smectite content could be expected. The SSA of the sample with the largest clay content, however, is smaller. This result may indicate the presence of micropores in the organic material. This finding is in accordance with that of Bernard et al. (2012) who reported increasing micro- and mesoporosity with increasing degree of maturation of the Posidonia shale. On the other hand, the results are also in accordance with those of Mann (1987) who reported smaller surface areas for samples with intermediate vitrinite reflectance (within the oil window). The trend published by Ropertz (1994) that carbonate-rich Posidonia shales are more porous is not reflected by the four samples in the present study.

The organic matter was investigated in further detail. The samples were dominated for the most part by lamalginite, bituminite, and liptodetrinite, all macerals very common in mature Posidonia Shales in the Lower Saxony Basin in Germany. Lamalginite occurs as finely banded lamellar algal bodies intermixed intimately with mineral matter in the sedimentary matrix. The filamentous benthonic and pelagic lamalginite bodies range in length between 10 and $\sim 40 \mu \mathrm{m}$. When coalesced, lamalginite may form thick strands up to $30-40 \mu \mathrm{m}$ wide. Bituminite is referred to as amorphous with no discrete form but of distinct optical properties. Its botanic origin remains largely unknown although it appears that it was derived from metabolic and anaerobic decay products of microorganisms. Liptodetrinite, because of its finely detrital nature and small particle size $(<10 \mu \mathrm{m})$, cannot be identified accurately. Its origin is inferred to be dominated by an algal precursor. Less abundant are large $(<10$ to $>60 \mu \mathrm{m})$, discrete unicellular algal bodies, which are referred to as telalginite. The large solitary Tasmanites algae appear as flattened, sutured discs representing fossil leiospheres (cysts) (Teichmüller and Ottenjann, 1977; Littke and Rullkötter; 1987; Littke et al., 1991). Other organic matter types such as the terrigenous vitrinite (auto- and allochthonous) and inertinite macerals as well as newly formed organic particles, i.e. solid bitumens, are of secondary importance and less common.

The vitrinite reflectance method has been used widely in determining the thermal maturity of organic matter in sedimentary rocks. The thermal maturity levels of four core samples examined from the western part of the Hils Syncline vary between $0.49 \% V R r$ and $1.42 \% \operatorname{VRr}$ (Table 4) and agree well with the data of Littke et al. (1988). The maturity determined appears to increase toward the northwest (Jochum et al. 1991). Thermal maturity investigations revealed that organic matter is mature to post-mature with regard to the oil-generative window. As expected, a correlation of the vitrinite reflectance with the organic matter content was found which can be explained by maturation of the organic matter. This is supported by Gorbanenko and Ligouis (2014) with examples of transformation of dispersed organic matter, i.e. telalginite during increase of thermal maturation and the resulting modification in morphology and size. The porosity in dispersed organic matter at a given thermal maturity results from its decomposition during hydrocarbon generation phase (Loucks et al. 2009; Modica and Lapierre, 2012) and may vary with maceral type (kerogen composition). 
Table 4. Thermal maturity data for the core samples examined of the Hils Syncline ( $V R r=$ random vitrinite reflectance, $N=$ number of measurements, $\mathrm{SD}=$ standard deviation, $\mathrm{Q}=$ Qualifier for the reliability of random vitrinite reflectance, derived from an evaluation of the surface structure of the vitrinite particles und statistical relevance, $5=$ very high reliability, $4=$ high, $3=$ average, $2=$ low, $1=$ very low, $0=$ not determinable or deducable).

\begin{tabular}{lcccc}
\hline Name & $\operatorname{VRr}(\%)$ & $N$ & SD & $Q$ \\
\hline Wickensen (WIC 9) & 0.49 & 26 & 0.07 & 3 \\
Dohnsen (DOH 10) & 0.70 & 10 & 0.04 & 2 \\
Dielmissen (DIE 15) & 0.65 & 29 & 0.05 & 3 \\
Haddessen (HAD 12) & 1.42 & 20 & 0.12 & 2 \\
\hline
\end{tabular}

\subsection{Direct methods}

3.2.1. $\mu-\mathrm{CT}$

The $\mu$-CT results obtained on the four different samples are shown in Figure 1. The segmentation process, in order to distinguish between the mineral matrix and void (pore) space, is extremely challenging for these respective dense and low phase-contrast rock materials (e.g. Krevor et al., 2015). Segmentation has been performed by grayscale analysis, using a mixture of manual and automatic threshold determinations (e.g. Otsu, 1979), in order to find the best possible parameter. Nevertheless, segmentation significantly under-estimates the sample porosity due to the low phase contrast within the shale samples. Note, in addition, that the smallest 'segmentable' pore is not as small as voxel resolution. As a rule of thumb, the smallest 'segmentable' feature is roughly in a range of voxel resolution $\times 3$ (e.g. a scan with $1 \mu \mathrm{m}$ voxel resolution will allow the user to segment features as small as $\sim 3 \mu \mathrm{m})$. Hence, the smallest pores which could be resolved in this study were $\sim 3.6-5 \mu \mathrm{m}$ in diameter (equivalent diameter). These files were then used to calculate a pore-size distribution. The data were also used to calculate a mean pore diameter but these values were obscured by the fact that many of the pores may be smaller than the detection limit of $\sim 4 \mu \mathrm{m}$, as described above. This is indicated by the pore-size distribution which proved that most of the pores were $<20 \mu \mathrm{m}$ and still increasing up to the lower detection limit. The porosity was calculated based on the segmented pores. Samples WIC and DIE contained more pores $(>2500$ were counted) than did samples DOH and HAD $(<1200$ pores). Furthermore, the segmented pore space was used to calculate the relative (or Euler) connectivity of the porous system, based on the workflow of Toriwaki and Yonekura (2002). The results of these calculations are consistent with the previous results and are visualized in Figure 2. For comparison, the results were normalized to an equivalent sample volume (here: $1 \mathrm{~mm}^{3}$ ). Samples DOH and HAD indicate clearly the smallest pore connectivity values (596 and 960, respectively). As shown in Figure 1 (middle section), the segmented pore system of these samples does consist of few pores which are more isolated. Sample WIC 9 has the greatest connectivity value (5048) and also the largest amount of segmented pores of all the shales investigated. Sample DIE 13 still has a large number of segmented pores related to samples $\mathrm{DOH}$ and HAD; but, contrary to WIC 9, the pore system is influenced by more isolated pores and microfractures (Figure 1, middle section). This explains reasonably well 


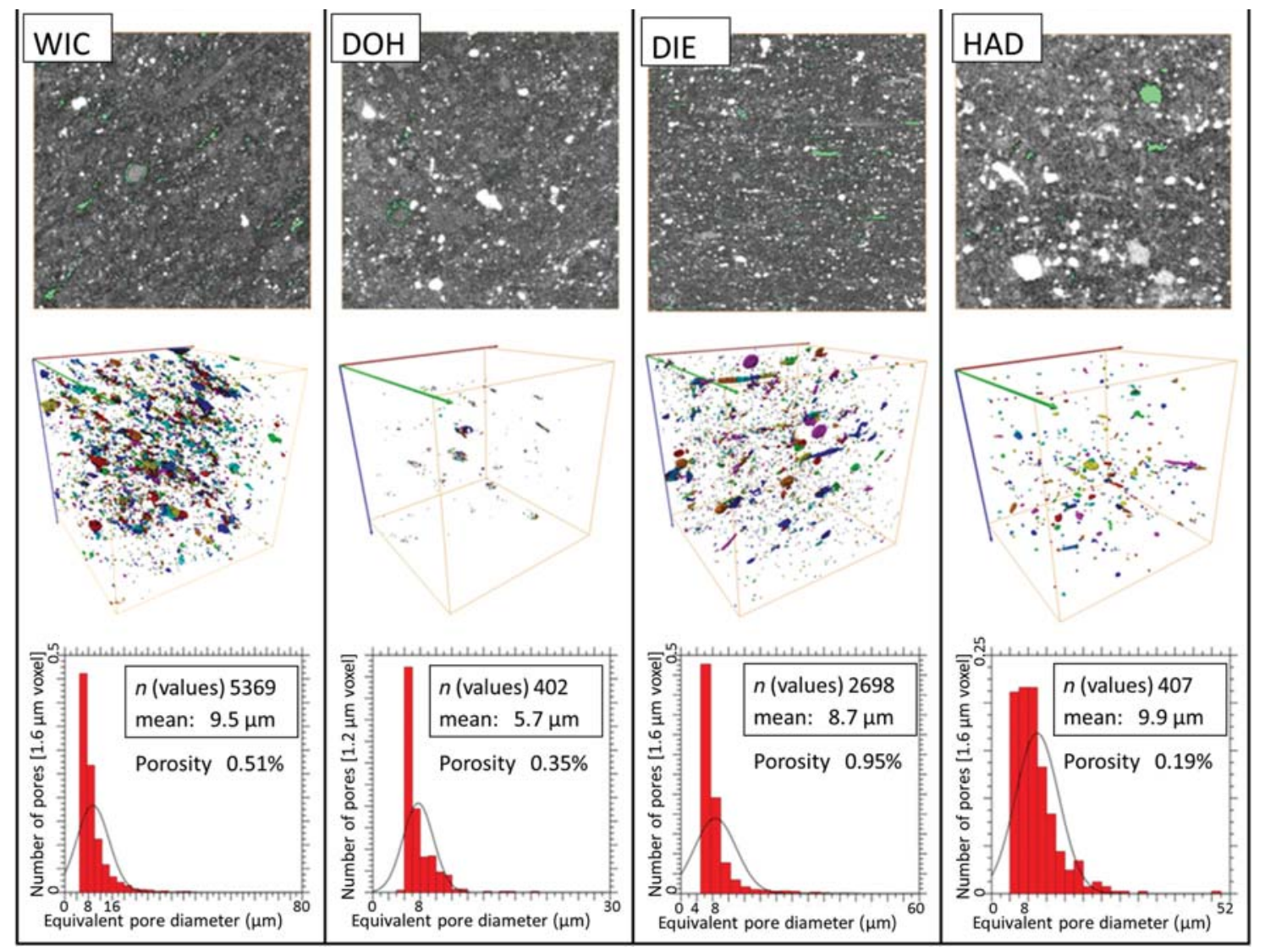

Figure 1. Results of $\mu$-CT investigation of the four different $1 \mathrm{~mm}^{3}$ sized samples. Upper row: 2D $\mu$-CT segment; middle row: 3D pore network (colors are to distinguish different pores but not different types or diameters); lower row: equivalent pore-diameter distributions. 


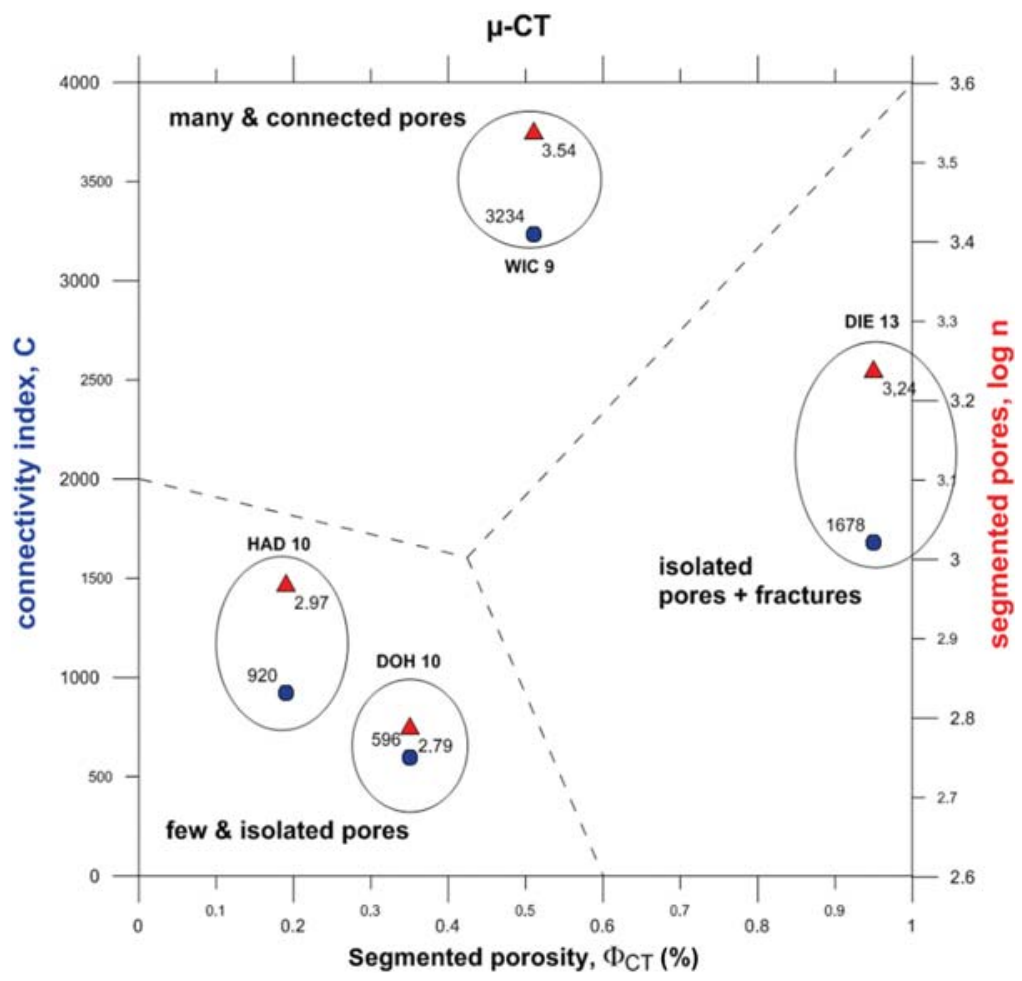

Figure 2. Results of the connectivity-index calculation and pore-system characterization based on the CT data sets of the shale samples investigated. The dashed lines are used to visualize different fields, the circles and ovals indicate data for a single sample.

the larger porosity value compared to that of WIC 9. If the fractures are removed from segmentation, connectivity will change just slightly, whereas porosity will decrease by $\sim 50 \%$ which would shift this sample to a position between the 'isolated pore' and 'connected pore' cluster. Fractures commonly show sharp and even walls and can be detected easily in the $\mu$-CT image. Such fractures were not observed.

For a more detailed characterization of the pore system of these shale samples, the total connectivity was split up and re-calculated for five different pore-size clusters. The cluster size was chosen as a compromise in terms of the pore-size distribution observed (Figure 1) and overall computational effort. By doing this, more information about the connectivity distribution related to the pore size was gained. The results for the $\mu$-CT data sets are shown in Figure 3.

Pores of $<10 \mu \mathrm{m}$ clearly have the greatest influence on connectivity indexes, ranging from $\sim 65 \%$ (HAD) to almost $98 \%$ (DOH) relative percentage of total connectivity. Because sample DOH 10 was scanned with a slightly higher resolution, even smaller pores $(<5 \mu \mathrm{m})$ were observed. After clustering and re-computation, the influence on connectivity is very distinctive: $\sim 52 \%$ of total connectivity is located in this cluster, 


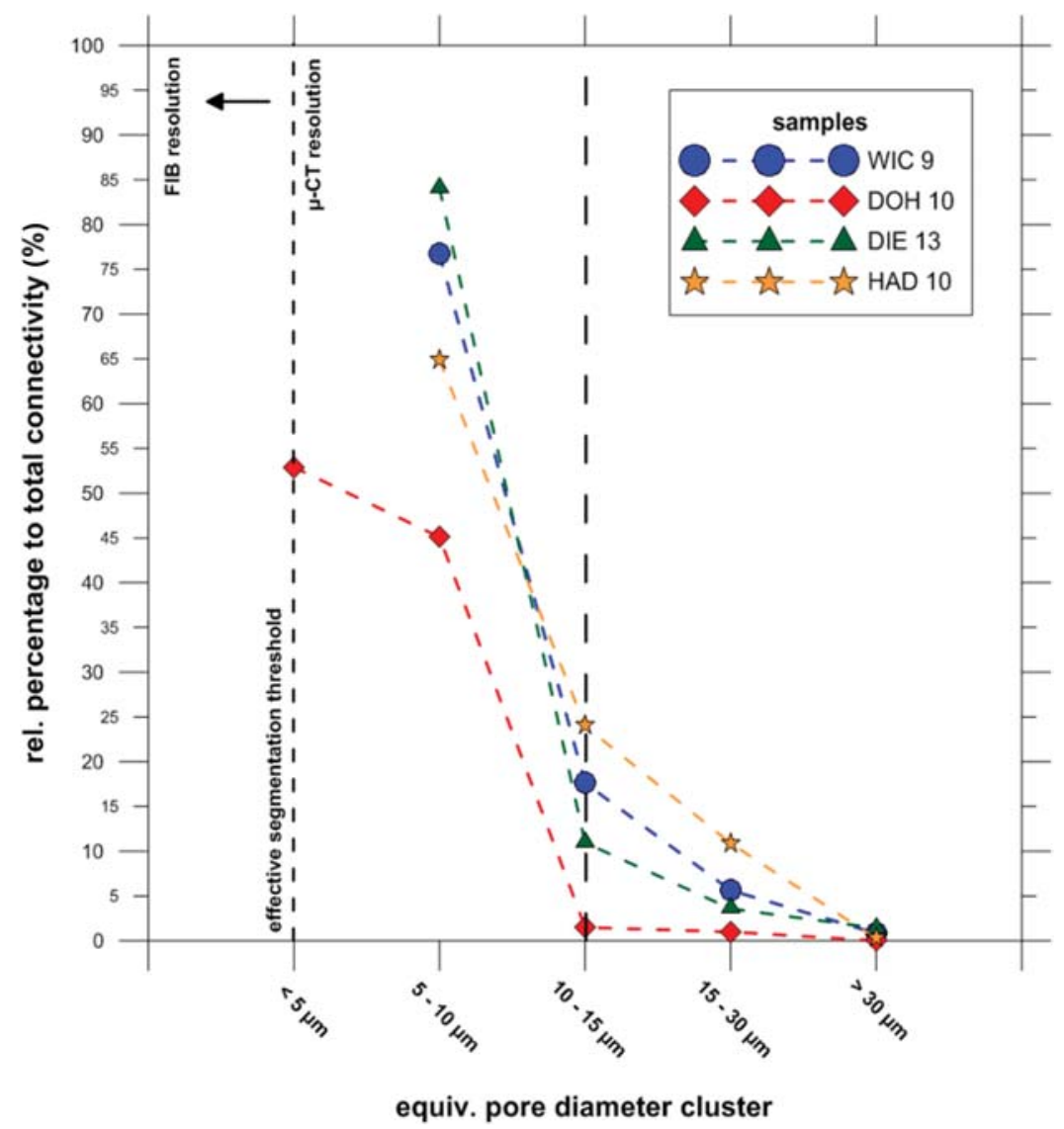

Figure 3. Results of the pore size-dependent connectivity analysis for the $\mu$-CT data sets of the Posidonia shale investigated.

followed directly by $\sim 46 \%$ within the $5-10 \mu \mathrm{m}$ cluster. In general, small pore sizes dominate clearly the total pore-system connectivity. For samples WIC, HAD, and DIE, pore-size clusters of $>15 \mu \mathrm{m}$ still contribute to total connectivity by up to $35 \%$. Only sample DOH indicates a different behavior, whereas the influence of larger pore sizes on connectivity is negligible (only $\sim 1.5 \%$ ).

\subsection{2. $F I B$}

The SEM images and data gained from segmented FIB analysis are shown in Figure 3. A $20 \mu \mathrm{m} \times 10 \mu \mathrm{m}$ section was ion milled to a depth of $10 \mu \mathrm{m}$ with a slice thickness of $25 \mathrm{~nm}$. Based on the gray scale of the SE images, the pores were segmented and marked in blue in the SEM images ( $1^{\text {st }}$ row of Figure 3$)$. 3D plots of pores of different sizes were obtained (also shown in Figure 3, rows 2-5). Finally, the minimum Feret diameters of 
the pores were selected to calculate a pore-size distribution (Figure 3, row 6). The FIB porosity was determined by summing up the volume of all the segmented pores. Smallscale pores, $28-120 \mathrm{~nm}$, are omnipresent in the samples and occur both in the inter- and intraparticle spaces. The small individual pores, making up large mesopores and very small macropores, are especially abundant in the mature organic matter, such as in the HAD sample. These are likely to have been filled with gas or oil at one time. Whether these pores are still filled with gas needs to be tested. In the less mature samples, very few pore spaces of $<120 \mathrm{~nm}$ were developed in the organic matter, while some macropores were developed. In these less mature samples, most of the pore space is developed in the carbonate, silicate, and clay matrices. The 3D segmentation shows disseminated small pores with a generally low connectivity. Larger pores, i.e. those from 120 to $360 \mathrm{~nm}$, apparently form some clusters which result in connectivity values of a few microns. This trend proceeds with pores of $>360 \mathrm{~nm}$. The amount of pores of $>360 \mathrm{~nm}$ decreased and connectivity may be restricted to a few $\mu \mathrm{m}$. The connectivity could neither be identified visually based on the different $3 \mathrm{D}$ images given in Figure 4, nor mathematically, for which the axis connectivity module in Avizo $\left.{ }^{(}\right)$was used, showing no axis connectivity in the $\mathrm{X}, \mathrm{Y}$, or $\mathrm{Z}$ directions. The connectivity is generally quite complex. As an example, a 3D image showing all pores $>1000 \mathrm{~nm}(1 \mu \mathrm{m})$, gave an impression of an extensive network of pores. On the other hand, the $2 \mathrm{D}$ sections of this 3D image suggest falsely the absence of any connectivity but some of these pores are connected in the third dimension. These plots cannot, therefore, be used to assess the connectivity. The calculation of the connectivity proved the presence of a few connected pores in the $\mu \mathrm{m}$ range. This view, however, is likely to be different if the pores of $<30 \mathrm{~nm}$ could be visualized.

As discovered using CT, the porosity of sample DOH was less than that of the other samples. The FIB pore-size distribution for all samples also resembles that of the $\mu$-CT pore-size distribution. A steady increase in the number of pores toward smaller diameters was observed, although FIB detected much smaller pores than $\mu$-CT. This suggests that the FIB porosity for the Posidonia shales with a resolution of $30 \mathrm{~nm}$ still may not represent the total porosity. The porosity of the four samples calculated from the segmented files is likely to be less than the actual porosity.

In addition to the $\mathrm{CT}$ data sets, connectivity values have been calculated as described in the previous section. The results are shown in Figure 5 and are consistent with and comparable to the distribution observed within Figure 2. The connectivity of sample HAD 10 has changed significantly compared to the previous analysis. On a CT-scale (i.e. a macropore scale), this sample is characterized as a mostly 'tight' sample, showing only a few and mostly isolated pores. On the FIB scale (i.e. mesopore scale), this changes dramatically in terms of calculated porosity, as well as in terms of calculated connectivity, due to the significantly better imaging resolution. The value of and need for different imaging techniques for a reasonable pore-system characterization of shales are clearly validated.

As for the $\mu$-CT data sets, the total connectivity of the FIB data investigated has been split up and re-calculated for four different pore-size clusters: $28-120 \mathrm{~nm}, 120-$ $360 \mathrm{~nm}, 360-1000 \mathrm{~nm}$, and $>1 \mu \mathrm{m}$ (again, referring to the analysis described for the 


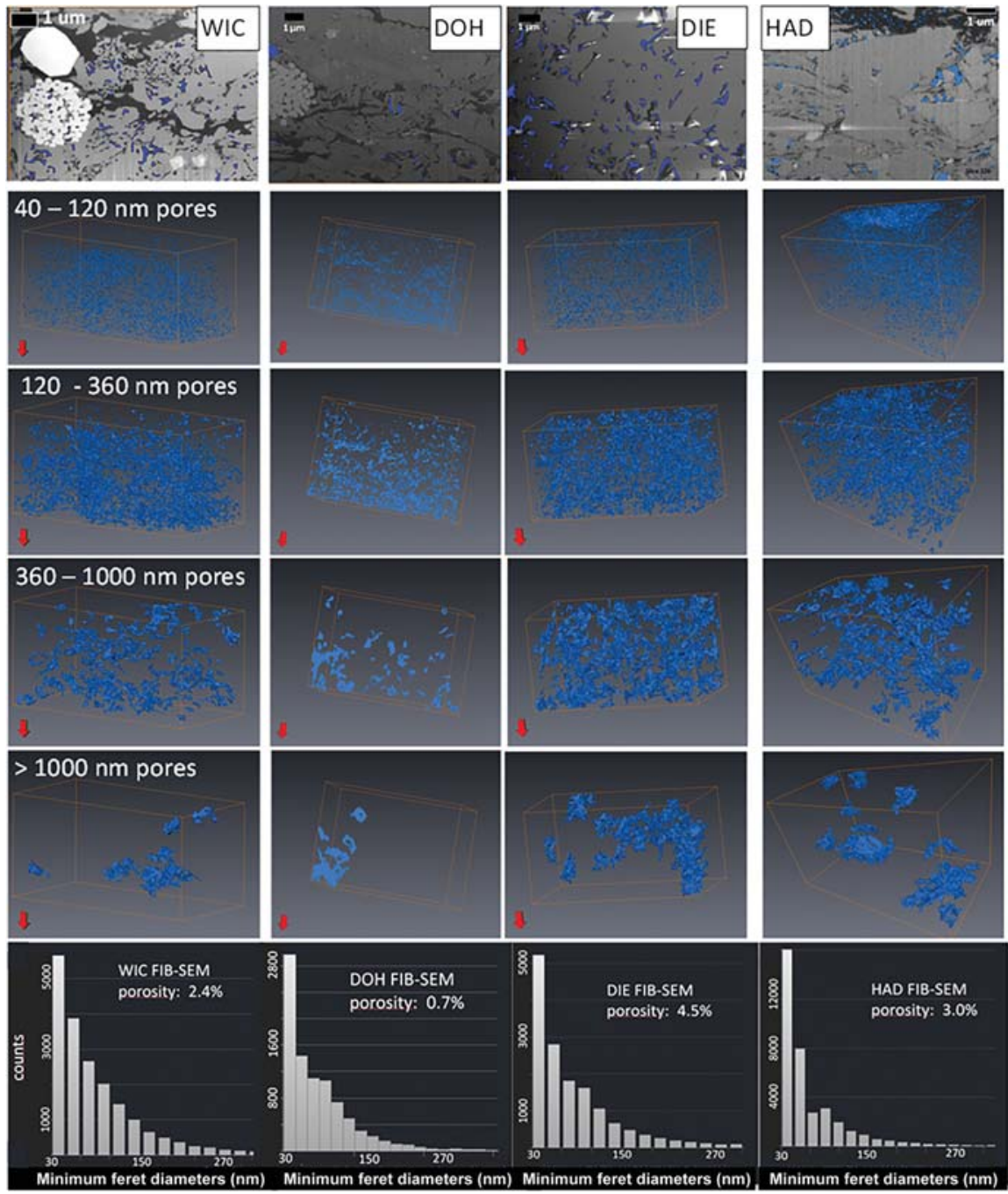

Figure 4. FIB results of the four different samples. Uppermost row: SEM images showing pores in blue; rows 2-5: 3D plots of pores of different sizes, lowest row: pore-size distribution.

CT data). The results are shown in Figure 6. In general, a similar trend can be observed, even on a significantly smaller scale than before. Most of the connectivity is linked to the first pore-size cluster $(28-120 \mathrm{~nm})$. This behavior continues almost linearly up to pore cluster three (360-1000 nm, except for sample HAD, which is slightly different). For the cluster which is $>1 \mu \mathrm{m}$, an interesting feature can be observed: whereas the cluster influence for samples WIC and DOH is negligible, the connectivity percentage increases significantly for the other two shales (up to $\sim 25 \%$ ). The connectivity of the 


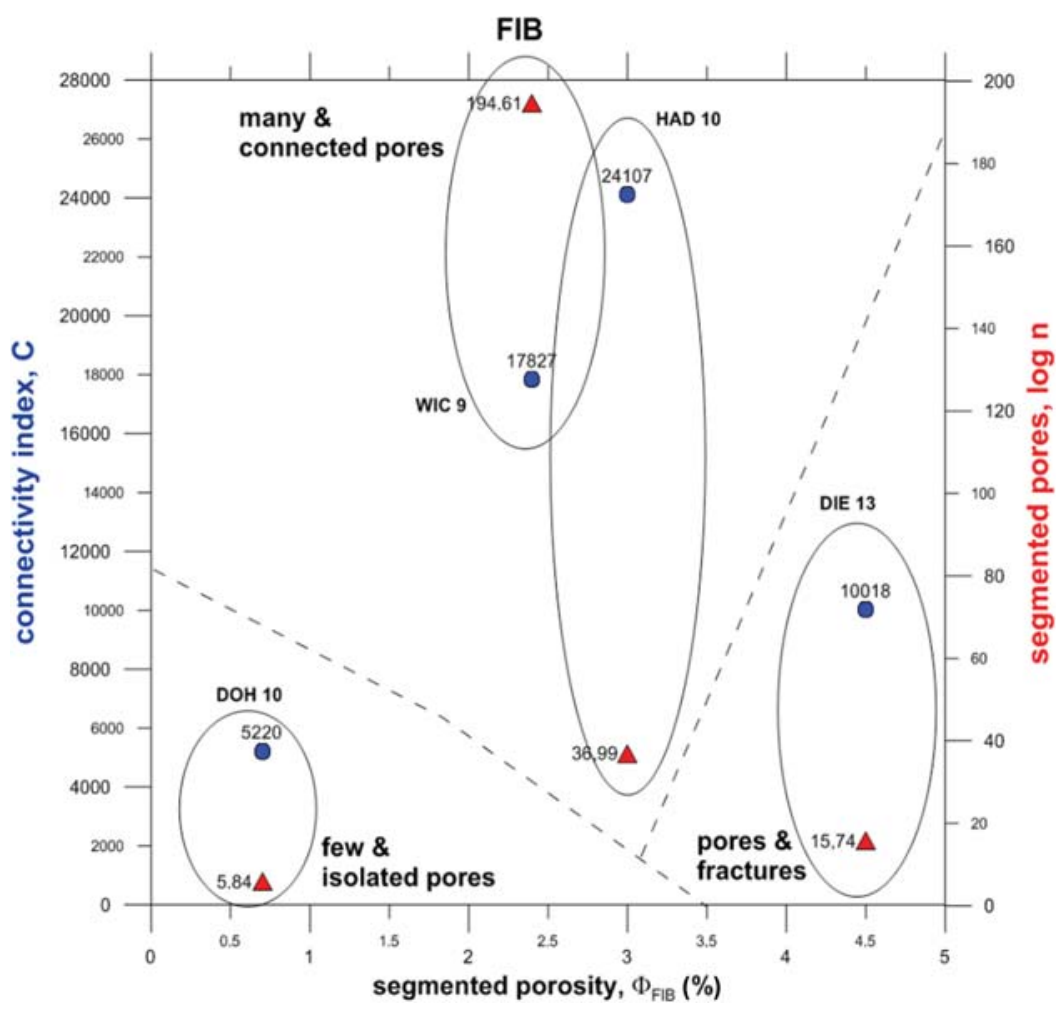

Figure 5. Results of the connectivity index calculation and pore-system characterization based on the FIB data sets of the shale samples investigated. The dashed lines are shown to visualize different fields, the circles and ovals surround a single sample.

pores detected by FIB (large mesopores + small macropores) of the four shale samples investigated is not distributed uniformly, unlike the CT connectivity of the macroporosity. This might be explained as an effect of the level of rock maturity or rock diagenesis, influencing directly the pore system at different scales.

\subsection{Indirect methods}

Three different indirect methods were used to characterize the porosity of the four Posidonia shale samples. $\mathrm{N}_{2}$ adsorption showed a sharp peak in the range of small mesopores $(\sim 4 \mathrm{~nm}=40 \AA)$ and a broad pore-size distribution toward macroporosity (Figure 7a). The shape of the curves, regardless of whether adsorption or desorption was considered, was similar for all samples. Sample HAD showed a particularly sharp peak at $\sim 40 \AA$, however, and that of sample DOH was smaller compared to the others. The position of the sharp $40 \AA$ peak was similar for all samples. The $\mathrm{Hg}$-intrusion method also proved a significant portion of mesopores and less macroprosity compared with $\mathrm{N}_{2}$ adsorption (Figure $7 b$ ). In contrast to $\mathrm{N}_{2}$ adsorption, the $\mathrm{Hg}$-intrusion method revealed different 


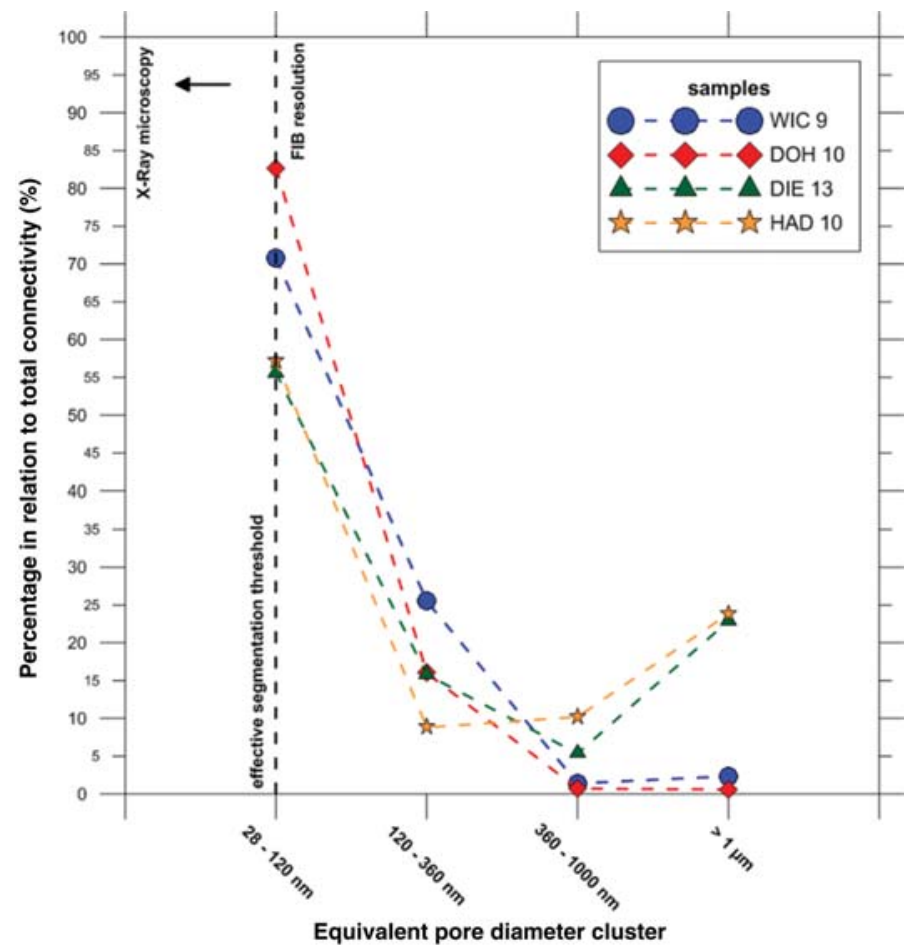

Figure 6. Results of the pore size-dependent connectivity analysis for the FIB data sets of the Posidonia shale investigated.

pore-size distributions in the mesopore range. Sample HAD showed a peak maximum at $\sim 30 \AA$ and the peak of sample WIC was at $\sim 200 \AA$. Samples DIE and DOH were in between $(\sim 5-6 \mathrm{~nm}=50-60 \AA)$. In contrast to $\mathrm{N}_{2}$ adsorption, no significant macroporosity was found. To characterize microporosity, $\mathrm{CO}_{2}$ adsorption was used. All samples showed a peak at $\sim 8 \AA$ and no significant differences between the four samples could be resolved (Figure 7c).

\section{Discussion}

The porosity measured with the different methods, with their relevant scales, and the vitrinite reflectance are summarized in Table 5 and discussed below. The $\mathrm{Hg}$-intrusion method probes the pore sizes from $2 \mathrm{~nm}$ to $60 \mu \mathrm{m}$, much larger than the $\mathrm{N}_{2}$-adsorption method, which probes from 2 to $200 \mathrm{~nm}$. The Hg-intrusion method is, therefore, generally better than the $\mathrm{N}_{2}$-adsorption method with respect to macropore characterization. The shale samples investigated in the present study have a low macroporosity, explaining why both methods provide similar total pore volumes. Both methods were, therefore, 


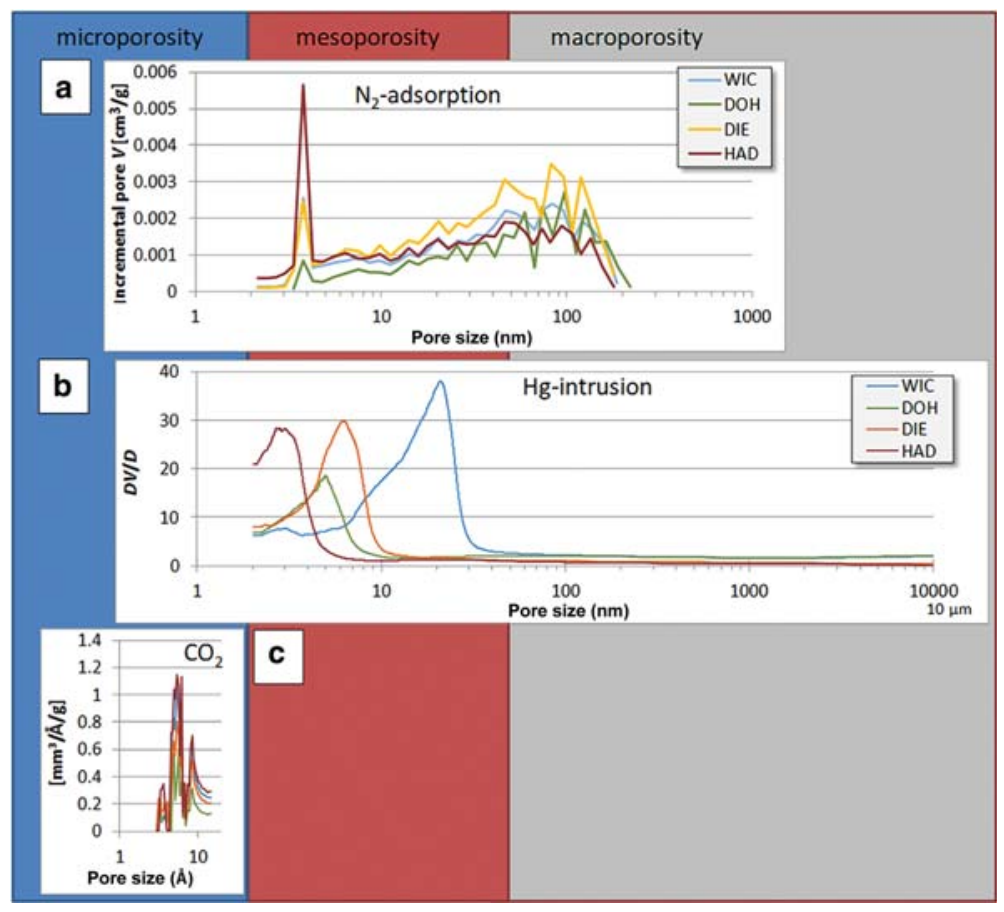

Figure 7. Results of the three indirect methods for the characterization of the porosity of the four shale samples: (1) $\mathrm{N}_{2}$ adsorption, (2) $\mathrm{Hg}$ intrusion, and (3) $\mathrm{CO}_{2}$ adsorption.

suitable for the characterization of the porosity of shales. The Hg-intrusion method showed different peak positions for the dominant mesoporosity, however, in contrast to $\mathrm{N}_{2}$ adsorption (all samples with a peak at $40 \AA$ ). None of the direct methods $(\mu$ $\mathrm{CT}$ and FIB) can visualize these pores to prove either equal (as indicated by $\mathrm{N}_{2}$ adsorption) or varying mesopore peaks (as indicated by $\mathrm{Hg}$ intrusion). Instead, the relation between the Hg-intrusion mesopore peak position with vitrinite reflectance was found (Figure 8a). The pore-size distribution decreased with increasing vitrinite reflectance indicating, therefore, that the mesopore peak was reduced upon increasing thermal maturity. The $\mathrm{N}_{2}$-adsorption peak corresponds to either micro- or mesoporosity but its constant character is surprising. This peak was observed for swelling clays poor in organic matter and can be reduced upon acid leaching (Kaufhold, 2001; Kaufhold and Decher, 2003). The mesopore peak position obtained from $\mathrm{N}_{2}$ adsorption is considered to be an artefact, probably caused by microporosity. The BJH method used to calculate the $\mathrm{N}_{2}$-adsorption pore-size distribution is applicable to mesopores. $\mathrm{N}_{2}$, however, also enters some micropores which cannot be calculated by the BJH method. This method, therefore, is not suitable to convert $\mathrm{N}_{2}$ adsorption data into a realistic pore-size distribution. This may explain the $40 \AA$ peak and why the peak is highest for the sample with the largest $\mathrm{CO}_{2}$ microporosity (HAD) and lowest for the sample with 
Table 5. Summary of all porosities determined with the different indirect and direct methods. All values were given in units of $\mathrm{mm}^{3} / \mathrm{g}(1 \%$ porosity corresponds to $4 \mathrm{~mm}^{3} / \mathrm{g}$, with a density of $2.5 \mathrm{~g} / \mathrm{cm}^{3}$ ).

\begin{tabular}{|c|c|c|c|c|c|c|c|c|c|c|c|c|c|c|}
\hline \multirow[b]{2}{*}{$\begin{array}{l}\text { Range } \\
\text { sample }\end{array}$} & \multirow{2}{*}{$\begin{array}{l}\begin{array}{c}\text { Vitrinite } \\
\text { refl. }\end{array} \\
(\%)\end{array}$} & \multicolumn{3}{|c|}{ He/dryflow ${ }^{\circledR}$-porosity } & \multicolumn{3}{|c|}{$\mathrm{N}_{2}$-adsorption } & \multicolumn{2}{|c|}{ Hg-porosimetry } & \multirow{2}{*}{$\begin{array}{c}\mathrm{CO}_{2} \text {-ads. } \\
\mathrm{CO}_{2} \\
--0.3-1.5 \mathrm{~nm}-- \\
\left(\mathrm{mm}^{3} / \mathrm{g}\right)\end{array}$} & \multirow[b]{2}{*}{$\begin{array}{c}--30-- \\
(\%)\end{array}$} & \multirow{2}{*}{$\frac{\text { FIB }}{} \begin{array}{c}1000 \mathrm{~nm}^{3}-- \\
\left(\mathrm{mm}^{3} / \mathrm{g}\right)\end{array}$} & \multicolumn{2}{|c|}{$\mu-C T$} \\
\hline & & \begin{tabular}{l} 
density \\
\hdashline$\left(\mathrm{g} / \mathrm{cm}^{3}\right)$
\end{tabular} & $\begin{array}{l}\quad 50 \mu \\
(\%)\end{array}$ & $\begin{array}{r}\text { porosity } \\
\left(\mathrm{mm}^{\mathbf{3}} / \mathrm{g}\right)\end{array}$ & $\begin{array}{c}\text { BET } \\
\left(\mathrm{m}^{2} / \mathrm{g}\right)\end{array}$ & $\begin{array}{c}\text { powder } \\
-2-200 \mathrm{n} \\
\left(\mathrm{mm}^{3} / \mathrm{g}\right)\end{array}$ & $\begin{array}{c}\text { granules } \\
\left.\mathbf{m}-\mathbf{m m}^{\mathbf{3}} / \mathrm{g}\right)\end{array}$ & $\begin{array}{c}\mathrm{Hg} \\
--2 \mathrm{~nm}-6 \\
\left(\mathrm{~mm}^{3} / \mathrm{g}\right)\end{array}$ & $\begin{array}{c}\text { peak } \\
\text { om-- } \\
(\mathrm{nm})\end{array}$ & & & & $\begin{array}{c}--5-- \\
(\%)\end{array}$ & $\begin{array}{l}80 \mu \mathrm{m}-- \\
\left(\mathrm{mm}^{3} / \mathrm{g}\right)\end{array}$ \\
\hline$\overline{\text { WIC } 9}$ & 0.49 & 2.40 & 15 & 61 & 9.8 & 59 & 25 & 64 & 20 & 4 & 2.4 & 10 & 0.5 & 2 \\
\hline DOH 10 & 0.70 & & 7 & 26 & 4.7 & 34 & 15 & 23 & 5 & 2 & 0.7 & 3 & 0.4 & 1 \\
\hline DIE 13 & 0.65 & 2.47 & 12 & 50 & 9 & 45 & 36 & 45 & 7 & 4 & 4.5 & 18 & 1.0 & 4 \\
\hline HAD 10 & 1.42 & 2.53 & 10 & 39 & 15.5 & 46 & 34 & 38 & 2 & 5 & 3.0 & 12 & 0.2 & 1 \\
\hline
\end{tabular}



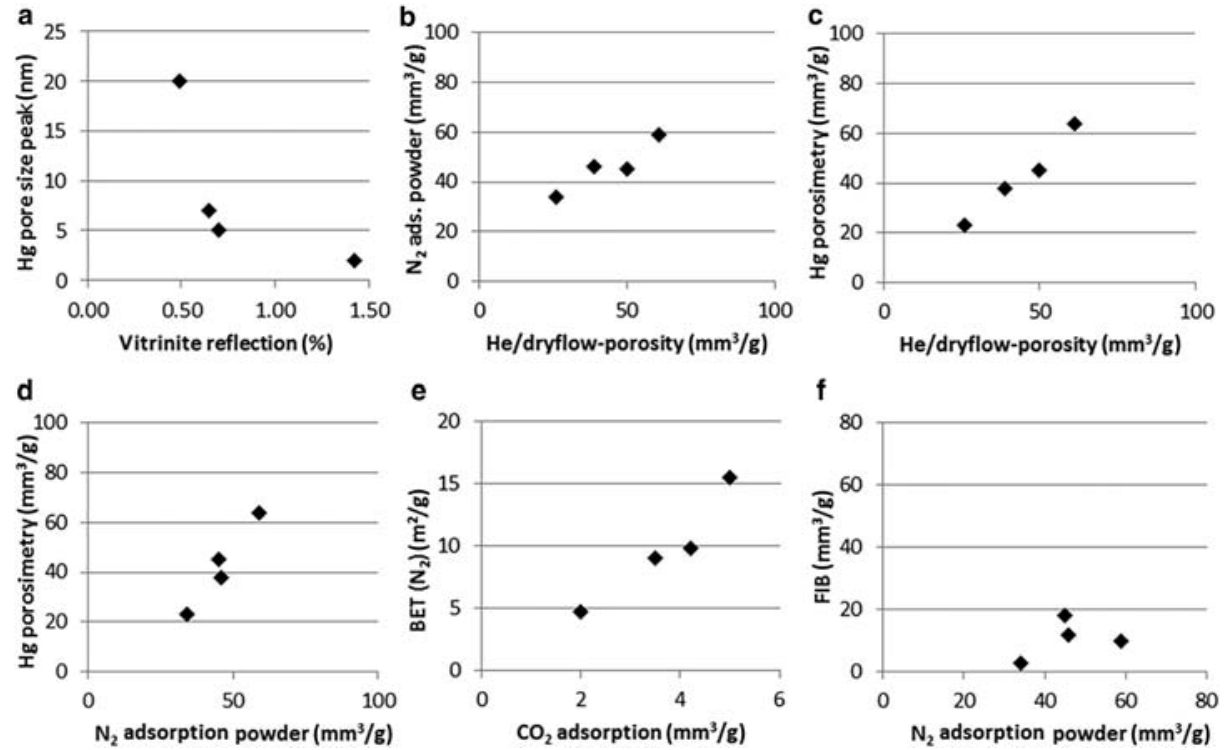

Figure 8. Comparison of the porosity and related parameters of the four shale samples.

the smallest $\mathrm{CO}_{2}$ microporosity (DOH). The pore volume determined by $\mathrm{N}_{2}$ adsorption is considered to be correct but the mesopore peak position is considered to be an artefact caused by the fact that $\mathrm{N}_{2}$ does not form a meniscus below $40 \AA$, a point which is accepted widely. The data presented here, however, indicate that the intensity of this peak correlates with the microporosity, a fact which can be used for comparison of samples, disregarding the absolute value. Overall, all three indirect methods, He/dryflow ${ }^{\circledR}$-pycnometry/porosimetry, $\mathrm{N}_{2}$ adsorption, and $\mathrm{Hg}$ intrusion, provide comparable pore volumes showing the same trends comparing the four samples (Figure $8 b-d$ ). The fourth indirect method, $\mathrm{CO}_{2}$ adsorption, cannot be compared with the others because it characterizes the microporosity only. It can be used to estimate the number of micropores which were not measured by any other method in the present study. On the other hand, a good correlation was found between the SSA determined by $\mathrm{N}_{2}$ adsorption and the $\mathrm{CO}_{2}$ microporosity (Figure 8e). This can be explained by the fact that the $\mathrm{N}_{2}$ BET-SSA of clays is known to be affected or even determined by the microporosity (Kaufhold et al., 2010, 2013).

A comparison of the pore volumes determined by FIB and $\mu$-CT is not reasonable because both clearly cover different ranges of pore sizes and significantly different volumes. $\mu$-CT provided values of $>5 \mu \mathrm{m}$, while FIB provided values between $30 \mathrm{~nm}$ and $1 \mu \mathrm{m}$. Because the macroporosities of the samples are small, as indicated by $\mathrm{N}_{2}$ adsorption and $\mathrm{Hg}$ intrusion, the pore volumes cannot be compared with any of the indirect methods. The macroporosity is proven to be small, however. The pore-size data obtained by FIB can be compared with either $\mathrm{N}_{2}$ adsorption- or $\mathrm{Hg}$ intrusion-derived values, however (the latter being highly correlated). The comparison 
of the FIB porosity values with $\mathrm{N}_{2}$-adsorption or $\mathrm{Hg}$-intrusion data indicated that only $20 \%$ of the pores can be visualized by FIB (Figure 8f).

Low macroporosity was found by all the shale-porosity studies. The actual values, however, may differ from one study to another. As an example, Klaver et al. (2012) found slightly lower porosity of the Posidonia shale (3-5\%), which can either be explained by different samples or by different maximum pressure used for $\mathrm{Hg}$-intrusion. About $7 \%$ porosity was reported by Kanitpanyacharoen et al. (2012), in good agreement with the present study. The orders of magnitude, however, seem to be similar for all shale samples. To compare different shales, the pore-size distribution determined by $\mathrm{Hg}$ intrusion is applicable. The pore-size distributions of three of the Posidonia shales are compared with data from some of the American gas shales published by Chalmers et al. (2012b; Figure 9). Sample Doig is a siltstone and hence not fully comparable with the other materials which are shales/claystones. The peak position found for the Woodford shale resembles that of sample DIE with intermediate vitrinite reflectance $(0.68 \%)$. The vitrinite reflectance of the Woodford sample, in contrast, was $\sim 1.5 \%$ and hence much larger than for sample DIE. The vitrinite reflectance-mesopore peak correlation may be valid for a specific basin or shale sequence only because no general trend could be observed.

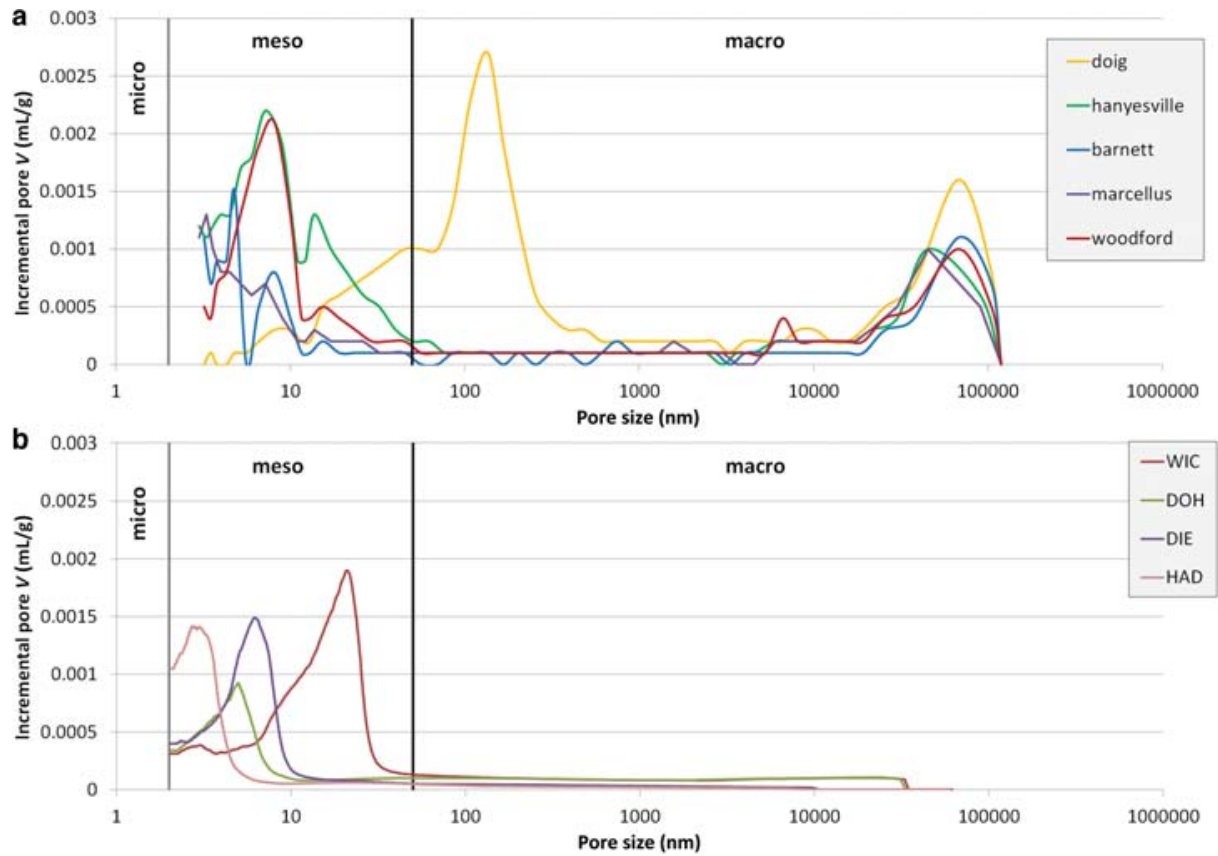

Figure 9. Comparison of the $\mathrm{Hg}$-intrusion porosity of a few North American gas shales: (a) data provided by Chalmers, pers. comm., 2014, published by Chalmers et al. (2012a) for the Posidonia shales; and (b) with significantly different maturity. 
The amount of gas produced from gas shale is variable which may be related to different pore structures such as connectivity. According to Chalmers et al. (2012a), the "interconnection between micropores, mesopores, macropores, and fractures is an important control on the matrix permeability...”. In principle, methane migration may take place by molecular diffusion and volume flow. Clays in which diffusion dominates can be regarded as more or less tight (Schlömer and Krooss, 1997). Keller et al. (2013) stated that pores of the Opalinus clay were connected in the $\mathrm{nm}$ range which is supposed to be too small for production of significant amounts of gas. Porosity of $>16 \mu \mathrm{m}$ (pore aperture) is needed for significant matrix permeability. The Hg-intrusion pore-size distributions of the Posidonia shales shown in Figure 9 were recorded at $<60 \mu \mathrm{m}$, in contrast to the results published by Chalmers et al. (2012a). The Hg porosity of $>10 \mu \mathrm{m}$ of Posidonia and the North American shales cannot be compared. Pores in the range of $100 \mu \mathrm{m}$ are important for gas production but can be better characterized by $\mu$-CT than by $\mathrm{Hg}$ porosimetry for which crushing of samples prior to analysis, at least, is required. $\mu$-CT results obtained on these samples showed few but unconnected pores above $5 \mu \mathrm{m}$. The FIB method proved some connected pores in the $\mu \mathrm{m}$-range, at $<10 \mu \mathrm{m}$. Connectivity over larger areas will probably exist if it were possible to include the pores that are $<30 \mathrm{~nm}$. Whether fracturing opened these pores to produce most of the gas remains an open question to be investigated using a real-scale test.

The different imaging techniques (CT and FIB) have highlighted the need for a combined multiple-scale approach, in order to characterize the pore system in the most comprehensive and meaningful way. It is possible to characterize different pore systems qualitatively and especially quantitatively at different scales. Qualitatively, a general pore system typing has been set based on 3D imaging. Different quantitative parameters, such as pore-size distribution and porosity, have been determined and may be used for further investigation. The dependence on resolution and phase segmentation must be taken into account as described. Different clusters of pores with different equivalent sizes dominate or, at least, participate in the connectivity calculated for the pore systems investigated. This does have some impact on the phenomenological description of (e.g. transport) processes at the pore scale.

All of the methods were conducted on dry and sometimes even crushed samples. The samples were taken from drill cores. The sample pretreatment may have resulted in the formation of pores considered to be artefacts. These pores cannot, of course, be related to gas-shale properties but their formation can hardly be avoided. The present study does not attempt to discuss these artefacts in detail. Instead samples were treated in a similar way to allow comparison. A comparison of samples and pore-size distributions obtained after different sample pretreatment and measured in different laboratories may not always be reasonable.

\section{Summary and conclusions}

The Posidonia shales investigated are dominated by submicrometer pores (typical of shales). Different methods were used to characterize the porosity. Direct methods 


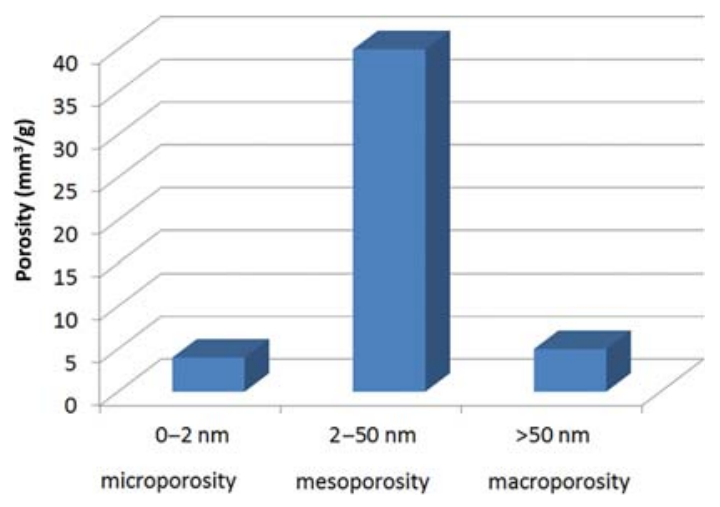

Figure 10. Average pore-size distribution of the four Posidonia shales investigated in the present study. such as $\mu$-CT and FIB can account for only $\sim 20 \%$ of the total porosity measured by the indirect methods. The most abundant porosity between 2 and $50 \mathrm{~nm}$ is too small for direct methods. These pores can scarcely be visualized. $\mathrm{N}_{2}$ adsorption, $\mathrm{Hg}$ intrusion, and He/Dryflow ${ }^{\circledR}$-pycnometry yielded a consistent characterization of the porosity, however. Accordingly, shales, or at least the Posidonia shales investigated, are dominated by mesoporosity, accounting for $30-40 \mathrm{~mm}^{3} / \mathrm{g}$ (corresponding to $7-10 \%$ ). Micro- and mesoprosity are $\sim 10 \%$ of the mesoporosity (Figure 10).

The Hg-intrusion method was found to be most suitable for characterizing gas shales because most of the pores, except for the micropores, are considered and the position of the mesopore peak seems to be meaningful, unlike $\mathrm{N}_{2}$ adsorption. The mesopore-size distribution which can be calculated based on $\mathrm{N}_{2}$-adsorption data using BJH or related algorithms is apparently affected by microporosity and, hence, does not resolve differences of the mesopore peak size which are important for gas shales. $\mathrm{N}_{2}$-adsorption is, however, suitable for measuring the pore volume because macroporosity is low.

Although FIB could not visualize most of the pores, the fact that a shale or claystone can be considered a porous medium from the perspective of a gas molecule is indicated. The connectivity, which is important for the production of shale gas, however, is assumed to be in the $>\mu \mathrm{m}$ range and can be measured by $\mu-\mathrm{CT}$. Gas adsorbed to micropores is said to be adsorbed strongly and not available for gas production. The micropore volume is small, however. Furthermore, FIB can be used to characterize the connectivity, which was different between the Posidonia shale samples. Whether a shale can be used for gas production or not depends on the brittleness, which depends on the mineralogical composition (Jarvie et al., 2007). Larger clay contents result in less brittleness, and the clay mineral content of gas shales should not be high, therefore (Passey et al., 2010). According to Andrews (2014), the clay content should be $<35$ mass $\%$. A $\mu \mathrm{m}$-sized pore between clay minerals (at least between illite and smectite) detected by any method using dry samples may not be open in a water-saturated state. The probability that pores exist between non-swellable particles, which would still be open when water-saturated, increases with decreasing clay content. Any porosity method, therefore, can only be used to try to distinguish shales with larger gas production potential if the mineralogical composition is considered. The porosity of the Posidonia shales studied is slightly greater than that of the North American formations, the clay content is similar, but the carbonate content 
is greater. Finally, to assess the production potential, the gas present has to be analyzed in situ, and hydraulic fracturing tests must be performed. The comparison of the porosity and the mineralogy of the Posidonia shale suggest an interesting gas shale although the macroporosity affecting the matrix permeability, which is important in terms of gas production, is apparently less than in some comparable North American gas shales.

\section{Acknowledgments}

Guest editor: H.C. Greenwell

The authors and editors are grateful to anonymous reviewers who offered very helpful input and suggestions. A list of all reviewers is given at the end of the Preface for this volume.

\section{References}

Andrews, I.J. (2014) The Jurassic shales of the Weald Basin: geology and shale oil and shale gas resource estimation. British Geological Survey for Department of Energy and Climate Change, London, UK.

Bernard, S., Horsfield, B., Schulz, H.-M., Wirth, R., Schreiber, A., and Sherwood, N. (2012) Geochemical evolution of organic-rich shales with increasing maturity: A STXM and TEM study of the Posidonia Shale (Lower Toarcian, northern Germany). Marine and Petroleum Geology, 31, 70-89.

Blumsack, S. (2014) Dash for gas, $21^{\text {st }}$ Century style! Elements, 10, 265-270.

Brunauer, S., Emmet, P., and Teller, E. (1938) Adsorption of gases in multimolecular layers. Journal of the American Chemical Society, 60, 309-319.

Brunke, O., Brockdorf, K., Drews, S., Müller, B., Donath, T., Herzen, J., and Beckmann, T. (2008) Comparison between X-ray tube based and synchrotron radiation based micro CT. Proceedings, Developments in $X$-ray Tomography VI, Vol. 7078. International Society of Optics and Photonics.

Buzug, T. (2005) Einführung in die Computertomographie - Mathematisch-physikalische Grundlagen der Bildrekonstruktion, $1^{\text {st }}$ edition. Springer Verlag, Berlin.

Chalmers, G.R., Bustin, R.M., and Power, I.M. (2012a) Characterization of gas shale pore systems by porosimetry, pycnometry, surface area, and field emission scanning electron microscopy/transmission electron microscopy image analyses: Examples from the Barnett, Woodford, Haynesville, Marcellus, and Doig units. American Association of Petroleum Geologists Bulletin, 96, 1099-1119.

Chalmers, G.R.L., Ross, D.J.K., and Bustin, R.M. (2012b) Geological controls on matrix permeability of Devonian Gas Shales in the Horn River and Liard basins, northeastern British Columbia, Canada. International Journal of Coal Geology, 103, 120-131.

Cui, Y., Kita, H., and Okamoto, K. (2004) Preparation and gas separation performance of zeolite T membrane. Journal of Materials Chemistry, 14, 924-932.

Curtis, J.B. (2002) Fractured shale gas systems. American Association of Petroleum Geologists Bulletin, 86, $1921-1938$.

Curtis, M.E., Ambrose, R.J., Sondergeld, C.H., and Rai, C.S. (2010) Structural characterization of gas shales on the micro- and nano-scales. Canadian Unconventional Resources and International Petroleum Conference. Society of Petroleum Engineers, Calgary, Alberta, Canada, p. 15. SPE 137693.

DIN 22020-5:1981-04. Rohstoffuntersuchungen im Steinkohlenbergbau; Mikroskopische Untersuchungen an Steinkohle, Koks und Briketts; Reflexionsmessungen an Vitriniten. Investigations of the raw material in hard-coal-mining; microscopical examinations of hard coal, coke and briquettes; reflectance measurements on vitrinites.

DIN 22020-5-:1986-09. Rohstoffuntersuchungen im Steinkohlenbergbau; Mikroskopische Untersuchungen an Steinkohle, Koks und Briketts; Reflexionsmessungen an Vitriniten. Investigations of the raw material in 
hard-coal-mining; microscopical examinations of hard coal, coke and briquettes; reflectance measurements on vitrinites.

DIN 22020-5:2005-02. Rohstoffuntersuchungen im Steinkohlenbergbau - Mikroskopische Untersuchungen an Steinkohle, Koks und Briketts - Teil 5: Reflexionsmessungen an Vitriniten. Investigations of the raw material in hard-coal-mining - Microscopical examinations of hard coal, coke and briquettes - Part 5: Reflectance measurements on vitrinites.

Dultz, S., Boy, J., Dupont, C., Halisch, M., Behrens, H., Welsch, A.M., Erdmann, M., Cramm, S., Helsch, G., and Deubener, J. (2014) Alteration of submarine basaltic glass under environmental conditions conducive for microorganisms: Growth patterns of the microbial community and mechanism of palagonite formation. Geomicrobiology Journal, 31, 813-834.

Gorbanenko, O.O. and Ligouis, B. (2014) Changes in optical properties of liptinite macerals from early mature to post mature stage in Posidonia Shale (Lower Toarcian, NW Germany). International Journal of Coal Geology, 133, 47-59.

Grangeat, P. (1990) Mathematical Methods in Tomography: Mathematical Framework of Cone Beam 3D Reconstruction via the First Derivative of the Radon Transform. Springer Verlag, Berlin.

Halisch, M. (2013) Application and assessment of the lattice Boltzmann method for fluid flow modelling in porous rocks. PhD thesis, Technische Universität Berlin, Germany, $208 \mathrm{pp}$.

IUPAC (J. Rouquérol, D. Avnir, C.W. Fairbridge, D.H. Everett, J.H. Haynes, N. Pernicone, J.D.F. Ramsay, K.S.W. Sing, and K.K. Unger) (1994) Recommendations for the characterisation of porous solids (Recommendations 1994). Pure and Applied Chemistry, 66, 1739-1758.

Jarvie, D.M., Hill, R.J., Ruble, T.E., and Pollastro, R.M. (2007) Unconventional shale-gas systems: The Mississippian Barnett Shale of north-central Texas as one model for thermogenic shale-gas assessment. American Association of Petroleum Geologists Bulletin, 91, 475-499.

Jochum, J., Leythaeuser, D., Littke, R., and Ropertz, B. (1991) Oil-bearing fluid inclusions in calcite-filled horizontal fractures from mature Posidonia Shale (Hils syncline, NW Germany). Pp. 160-162 in: Organic Geochemistry. Advances and Applications in Energy and the Natural Environment (D.A.C. Manning, editor). Manchester University Press, Manchester, UK.

Kanitpanyacharoen, W., Kets, F.B., Wenk, H.-R., and Wirth, R. (2012) Mineral preferred orientation and microstructure in the Posidonia shale in relation to different degrees of thermal maturity. Clays and Clay Minerals, 60, 315-329.

Kaufhold, S. (2001) Untersuchungen zur Eignung von natürlich alterierten sowie mit Oxalsäure aktivierten Bentoniten als Bleicherde für Pflanzenöle. Doctoral thesis of the RWTH Aachen, Germany, 188 pp.

Kaufhold, S. and Decher, A. (2003) Natural acid bentonites from Milos island, Greece. Zeitschrift für Angewandte Geologie, 49, 7-12.

Kaufhold, S., Dohrmann, R., Klinkenberg, M., Siegesmund, S., and Ufer, K. (2010) N N$_{2}$ BET specific surface area of bentonites. Journal of Colloid and Interface Science, 349, 275-282.

Kaufhold, S., Plötze, M., Klinkenberg, M., and Dohrmann, R. (2013) Density and porosity of bentonites. Journal of Porous Materials, 20, 191-208.

Keller, L.M., Holzer, L., Wepf, R., and Gasser, P. (2011) 3D geometry and topology of pore pathways in Opalinus clay: Implications for mass transport. Applied Clay Science, 52, 85-95.

Keller, L.M., Schuetz, P., Erni, R., Rossell, M.D., Lucas, F., Gasser, P., and Holzer, L. (2013) Characterization of multi-scale microstructural features in Opalinus Clay. Microporous and Mesoporous Materials, 170, 83-94.

Kennedy, M.J., Löhr, S.C., Fraser, S.A., and Baruch, E.T. (2014) Direct evidence for organic carbon preservation as clay-organic nanocomposites in a Devonian blackshale; from deposition to diagenesis. Earth and Planetary Science Letters, 388, 59-70.

Klaver, J., Desbois, G., Urai, J.L., and Littke, R. (2012) BIB-SEM study of the pore space morphology in early mature Posidonia Shale from the Hils area, Germany. International Journal of Coal Geology, 103, 12-25.

Krevor, S., Blunt, M.J., Benson, S.M., Pentland, C.H., Reynolds, C., Al-Menhali, A., and Niu, B. (2015) Capillary trapping for geologic carbon dioxide storage - From pore scale physics to field scale implications. International Journal of Greenhouse Gas Control, 40, 221-237. 
Littke, R., and Rullkötter, J. (1987) Mikroskopische und makroskopische Unterschiede zwischen Profilen unreifen und reifen Posidonienschiefers aus der Hilsmulde. Facies, 17, 171-179.

Littke, R., Baker, D.R., and Leythaeuser, D. (1987) Microscopic and sedimentologic evidence for the generation and migration of hydrocarbons in Toarcian source rocks of different maturities. Advances in Organic Geochemistry, 13, 549-559.

Littke, R., Baker, D.R., and Leythaeuser, D. (1988) Microscopic and sedimentologic evidence for the generation and migration of hydrocarbons in Toarcian source rocks of different maturities. Organic Geochemistry, 13, 549-559.

Littke, R., Leythaeuser, D., Rullkötter, J., and Baker, D.R. (1991) Keys to the depositional history of the Posidonia Shale (Toarcian) in the Hils Syncline, northern Germany. Pp. 311-333 in: Modern and Ancient Continental Shelf Anoxia (R.V. Tyson, editor). Special Publications, 58, Geological Society, London.

Loucks, R.G., Reed, R.M., Ruppel, S.C., and Jarvie, D.M. (2009) Morphology, genesis, and distribution of nanometer-scale pores in siliceous mudstones of the Mississippian Barnet shale. Journal of Sedimentary Research, 79, 848-861.

Mann, U. (1987) Veränderung von Mineralmatrix und Porosität eines Erdölmuttergesteins durch einen Intrusivkörper (Lias epsilon 2-3: Hilsmulde, NW-Deutschland). Facies, 17, 181-188.

Milliken, K.L., Rudnicki, M., Awwiller, D.N., and Zhang, T. (2013) Organic matter-hosted pore system, Marcellus formation (Devonian), Pennsylvania. American Association of Petroleum Geologists Bulletin, 97, 177-200.

Modica, C.J. and Lapierre, S.G. (2012) Estimation of kerogen porosity in source rocks as a function of thermal transformation; example from the Mowry Shale in the Powder River basin of Wyoming. American Association of Petroleum Geologists Bulletin, 96, 87-108.

Otsu, N. (1979) A threshold selection method from gray-level histograms. IEEE Transactions on Systems, Man, and Cybernetics, SMC-9, 62-66.

Passey, Q.R., Bohacs, K.M., Esch, W.L., Klimentidis, R., and Sinah, S. (2010) From Oil-Prone Source Rock to Gas-Producing Shale Reservoir - Geologic and Petrophysical Characterization of Unconventional Shale-Gas Reservoirs. Paper SPE 131350, CPS/SPE International Oil and Gas Conference and Exhibition in China held in Beijing, China, 8-10 June 2010.

Rexer, T.F., Mathia, E.J., Aplin, A.C., and Thomas, K.M. (2014) High-pressure methane adsorption and characterization of pores in Posidonia Shales and isolated kerogens. Energy Fuels, 28, 2886-2901.

Ropertz, B. (1994) Wege der primären Migration: Eine Untersuchung über Porennetze, Klüfte und Kerogennetzwerke als Leitbahnen für den Kohlenwasserstoff-Transport. PhD study FZJ, Institut für Chemie und Dynamik der Geosphäre 4: Erdöl und Organische Geochemie, 358 pp.

Ross, D.J.K. and Bustin, R.M. (2007) Impact of mass balance calculations on adsorption capacities in microporous shale gas reservoirs. Fuel, 86, 2696-2706.

Ross, D.J.K. and Bustin, R. M. (2008) The Importance of Pore Structural Heterogeneities for Shale Gas Reservoir Evaluation. American Association of Petroleum Geologists Datapages - Search and Discovery Article \#110071.

Ross, D.J.K. and Bustin, R.M. (2009) The importance of shale composition and pore structure upon gas storage potential of shale gas reservoirs. Marine and Petroleum Geology, 26, 916-927.

Rullkötter, J., Leythaeuser, D., Horsfield, B., Littke, R., Radke, M., Schaeffer, R.G., Schenk, H.-J., Schwochau, K., Witte, E.G., and Welte, D.H. (1988) Organic matter maturation under the influence of a deep intrusive heat source: A natural experiment for quantitation of hydrocarbon generation and expulsion from a petroleum source rock (Toarcian shale, northern Germany). Organic Geochemistry, 13, 847-856.

Schieber, J. (2011) Shale Microfabrics and Pore Development - An Overview with Emphasis on the Importance of Depositional Processes. Recovery - 2011 CSPG CSEG CWLS Convention.

Schlömer, S. and Krooss, B.M. (1997) Experimental characterization of the hydrocarbon sealing efficiency of cap rocks. Marine and Petroleum Geology, 14, 565-580.

Taylor, G.H., Teichmüller, M., Davis, A., Diessel, C.F.K., Littke, R., and Robert, P. (1998) Organic Petrology. Gebr, Borntraeger, Berlin, 704 pp.

Teichmüller, M. and Ottenjann, K. (1977) Liptinite und lipoid Stoffe in einem Erdölmuttergestein. Erdöl Kohle, 30, 387-398. 
Toriwaki, J. and Yonekura, T. (2002) Euler number and connectivity indexes of a three dimensional digital picture. Forma, 17, 183-209.

Viggiani, G., Bésuelle, P., and Desrues, J. (2013) X-ray Microtomography as a tool for studying localized damage/deformation in clay rock. Clay Characterisation from Nanoscopic to Microscopic Resolution, NEA CLAY CLUB. Workshop Proceedings, Karlsruhe, Germany, 6-8 September 2013, https:// www.oecd-nea.org/rwm/docs/2013/rwm-clayclub2013-1.pdf, pp. 91-98.

Warr, L.N. and Grathoff, G. (2011) Geoscientific applications of particle detection and imaging techniques with special focus on the monitoring clay mineral reactions. Pp. 669-683 in: Handbook of Particle Detection (C. Grupen, editor). Springer, Berlin.

Washburn, E.W. (1921) Note on a method of determining the distribution of pore sizes in a porous material. Proceedings of the National Academy of Science, USA, 7, 115-116.

Webb, P.A., and Orr, C. (1997) Analytical methods in fine particle technology. Micromeritics Instrument Corp, Norcross, Georgia, USA. 